\title{
Bank competition and firm credit availability: firm-bank evidence from Europe
}

\author{
Pietro Grandi ${ }^{*}$ and Caroline Ninou Bozou ${ }^{\dagger}$
}

September 14, 2018

\begin{abstract}
This paper examines the impact of bank competition on firms' access to credit using a large panel of 900 banks matched to almost 60.000 firms across the euro area over the period 20102016. Results provide empirical support for the market power hypothesis whereby low interbank competition worsens firms' credit conditions. We find that higher bank market power is associated with lower short-term bank credit and higher trade credit for customer firms. Furthermore, high bank market power is especially detrimental for small, low quality and opaque firms, suggesting that lower inter-bank competition exacerbates the financial constraint of borrowers that are more exposed to information problems. By contrast, we find limited evidence consistent with the information hypothesis: among firms related to banks with high market power, only those served by small and local cooperatives obtain more bank credit. This finding highlights the relative importance of specialisation, ownership structure and local outreach in favouring credit relationships between borrowers and lenders.
\end{abstract}

Keywords: Banks, inter-bank competition, firms' access to finance.

fEL classification: G21, G32, D22, D40.

"LEMMA, Université Paris 2 (Panthéon-Assas), 92 rue d'Assas, 75270 Paris, France.

†LEMMA, Université Paris 2 (Panthéon-Assas), 92 rue d’Assas, 75270 Paris, France. 


\section{Introduction}

Does inter-bank competition ultimately benefits firms' access to credit? Unlike most industries, the peculiar features inherent to the banking business and the key role of information prevent a straightforward answer. Indeed, economic theory makes conflictive predictions on whether borrowers benefit from competition between lenders. On the one hand, the market power hypothesis holds that greater competition leads to higher and cheaper allocation of credit to firms (Pagano, 1993). On the other hand, the information hypothesis argues that banks are more likely to form long-term relationships with borrowers when operating in a non-competitive market. Strong competition would hence discourage relationship lending and impair firms' access to credit (Petersen and Rajan, 1995; Dell Ariccia and Marquez, 2006).

Current renewed interest in banking consolidation across the European Union (EU) further underscores the salience of this issue. The move to a Banking Union is expected to usher in greater cross-border banking consolidation by creating a large EU-wide banking market (Schoenmaker and Wierts, 2015). Furthermore, there is a widespread concern that the EU's over-reliance on banks has adverse implications for financial stability and economic growth (Langfield and Pagano, 2016; Nuoy, 2017). ${ }^{1}$ As a result, EU policy makers tend to welcome cross-border banking consolidation as a vector of European financial integration and a remedy to bank bias (Nuoy, 2017). However, less attention is being devoted to the potential implications of greater bank concentration on corporate credit conditions.

In this paper we empirically investigate the impact of inter-bank competition on firms' access to credit by using a database that matches almost 60.000 firms to 900 banks located in the euro area over the period 2010-2016. The structure of the data allows to directly test how a bank's market power - as measured by the Lerner index at the bank level - affects the credit availability of its customer firms. Similarly to Amiti and Weinstein (2011), we exploit the variation in the credit availability of firms within the same industry but related to banks with different levels of market power. This procedure allows to identify the effect of bank competition on financial constraint net of industry-wide credit demand. Lender and borrower specific determinants of financial constraint are also controlled for through balance sheet and income statement information at both firm and bank level.

We find evidence that rejects the information hypothesis in favour of the market power hypothesis: weaker inter-bank competition is associated with lower short-term bank credit and higher reliance on trade credit for customer firms. Moreover, higher bank market power is especially detrimental for credit availability precisely where the information hypothesis predicts it should be most beneficial: Among firms related to banks with high market power, small, low quality and opaque firms receive less short-term bank credit and more trade credit than large, high quality and transparent firms. Importantly, this result is replicated by restricting the sample to SMEs only. Furthermore, for a given level of bank market power, SMEs related to a single bank obtain less short-term bank credit than SMEs serviced by multiple banks. Conversely, we find only limited evidence consistent with the information hypothesis: Among firms related to banks with high market power, those served by small and local cooperatives obtain more bank credit as compared to those served by large commercial or savings banks.

Overall, we consider our results to be mostly consistent with the market power hypothesis, whereby lower inter-bank competition exacerbates the financial constraint of borrowers more exposed to information problems. By contrast, the limited evidence supporting the information hypothesis suggests lower inter-bank competition may improve access to credit insofar it nur-

\footnotetext{
${ }^{1}$ The EU banking market is large by international standards: as of 2017 , total banking assets accounted for $280 \%$ of GDP. By comparison, total assets of the US banking sector accounted for just 88\% of GDP (Nuoy, 2017).
} 
tures credit relationships established at the local level between small cooperatives and small firms who have a strong interest in forming long-term relationships.

To the best of our knowledge, this is the first study employing firm-banks matched data to measure the effect of bank competition on firms' financial constraint. As noted by Ryan et al. (2014b), the explicit focus on lenders-borrowers relationships allows for a deeper analysis of the determinants of firms' access to finance. In this respect, this paper makes the following contributions. First, we are able to uncover and measure important heterogeneities in how bank competition affects credit availability across both firms and banks. The finding that bank competition does not affect all firms and banks in the same manner has potential consequence for competition policies aimed at maintaining a competitive banking environment and the provision of credit to firms, in particular to SMEs. Second, we improve on the identification of the effect of bank competition on access to credit by looking at how firms linked to banks with different market power draw resources from alternative funding sources - that is, whether they substitute bank with trade credit. This procedure allows us to test more precisely whether higher bank market power alleviates or exacerbates firms' financial constraint.

This paper is structured as follows. Section 1 reviews the related literature and presents the hypotheses that will be tested in the empirical analysis. Section 2 presents the database and considers our derivation of the Lerner index as measure of bank market power. The identification strategy and the econometric model are also discussed. Results are presented in section 4, while section 5 provides concluding remarks.

\section{Related literature}

Economic theory yields two contradictory predictions on the relation between bank competition and firms' access to credit: the market power hypothesis and the information hypothesis. ${ }^{2}$

A direct application of standard competition theory to the banking industry, the market power hypothesis maintains that less competitive banking markets lead to restricted credit allocation at a higher price. For instance, using an endogenous growth model, Pagano (1993) infers that high bank market power engenders $\mathrm{X}$-inefficiencies in the absorption and intermediation of resources, thus leading to higher interest rates for borrowers. In the same vein, Guzman (2000) compares two model economies differing only in the degree of bank competition to show that monopoly banking is more likely to lead to credit rationing than competitive banking. Vives (2001) argues that, not unlike other industries, competitive pressure allows for innovation and the expansion of services, in turn encouraging the extension of credit to a pool of borrowers previously excluded by institutional finance.

By contrast, the information hypothesis argues that lower inter-bank competition is associated with higher credit availability. This view is centred on credit relationships between lenders and borrowers. Since limited competition encourages relationship building and inter-temporal sharing of surplus between banks and firms, a monopolistic lender may be more willing to offer credit than a similarly placed lender in competitive market (Petersen and Rajan, 1994, 1995). ${ }^{3}$ Strong

\footnotetext{
${ }^{2}$ See Cetorelli (2001b) for an overview about the theoretical and empirical literature on bank concentration.

${ }^{3}$ As noted by Petersen and Rajan (1995), a monopolistic lender may be able to share in the future surplus of the firm through the future rents the former will be able to extract. For instance, the lender may back-load interest payments over time, so to subsidize the firm in bad times and extracting rents in good times. The same argument is made by Mayer (1988) who suggests that a monopolistic bank may be willing to provide credit to a distressed firm as it expects to reap a share of the firm's future profit in the form of higher interest rate payments. By contrast, a bank operating in a competitive market would expect the firm to switch to cheaper funding alternatives as soon it recovers financial health, which would discourage the bank to provide rescue funding to begin with.
} 
competition on credit markets may instead be incompatible with the creation of mutually beneficial relationships between borrowing firms and creditor banks. Similarly, Marquez (2002) shows that in more competitive banking systems, borrower-specific information tends to become more dispersed, thus entailing less efficient screening and higher lending rates. Dell Ariccia and Marquez (2006) provide additional theoretical arguments suggesting that increased competition on credit markets is associated with higher credit availability for "informationally captured" firms, resulting in lower quality of informed bank loan portfolios.

Subsequent empirical work tested the theoretical predictions implied by the two theories. For instance, using a panel of 74 countries and an index of firm credit constraint built from survey data, Beck et al. (2004) find that high bank concentration - as measured by banking regulatory policies and by the market share of the largest three domestic banks - tends to increase firms' reported obstacles to obtain finance, a result in line with the market power hypothesis. Similar evidence is documented by Love and Martínez Pería (2015). Drawing on bank level data and firm level surveys from 53 countries, the authors find bank concentration - as captured by the Lerner and Boone indexes at the country level - to be negatively associated with firms' access to credit but significantly less so in countries with more developed private credit information sharing schemes such as credit bureaus and credit registries. Leon (2015) uses firm level data on 69 developing and emerging countries and finds that firms' credit constraint, as derived by responses to a survey, appears to be alleviated by bank competition, as measured through three non-structural indicators: the Lerner index, the Panzar-Rosse H-statistic, and the Boone indicator. Furthermore, using firm level data on Spanish SMEs matched to regional bank data, Carbo Valverde et al. (2009) study how bank market power affects firm's reliance on trade credit, taken as a proxy of financial constraint. The authors find that results crucially depend on the specific measure of bank market power employed - that is, structural or non-structural. Specifically, results indicate a negative association between bank market power and credit availability when banks' competition is captured by the Lerner index, while results are reversed if the HHI is employed. Furthermore, Jayaratne and Wolken (1999) and Berger and et al (2004) fail to find a relation between concentration and dependence on trade credit, while Degryse et al. (2007) note that more concentrated market are characterised by significantly larger spreads in both deposit and loan markets.

Other papers provide evidence in favour of the information hypothesis. For example, using U.S. Internal Revenue Service data on small firms, Zarutskie (2006) finds that newly formed firms - hence those more exposed to informational asymmetries - have significantly less outside debt in more competitive banking markets, and suggests this may be due to the fact that stronger competition discourages lenders from financing new firms whith unknown credit quality. Cetorelli (2001a) and Bonaccorsi di Patti and Dell'ariccia (2004) find that higher concentration is positively related to growth in industrial sectors that are more dependent on external finance. More recently, using a panel of firms from 20 European countries covering the period 2001-2011, Fungáčová et al. (2014) find that stronger bank competition (as measured by both structural and non-structural metrics at the country-level) tends to increase the cost of credit for corporate borrowers, particularly so for small firms.

While the balance of evidence comes down on the side of the market power hypothesis, reviewed studies differ widely in data disaggregation, geographic scope, time period and choice of the indicators to capture bank competition and access to credit, making it difficult to generalise their results. Furthermore, most studies use country level measure of bank competition whereas relevant banking markets may be regional or local in nature (Maudos and Fernndez de Guevara, 2007; Berger et al., 2009; Fungáčová et al., 2014; Drechsler et al., 2017). Third, all reviewed empirical studies are at the firm level. We contend that these approaches have two main limitations: i) they cannot completely isolate banks' supply of and firms' demand for credit; and ii) they ne- 
glect the role of lender-borrower relationships which may be crucial to discriminate between the market power and information hypotheses.

We contribute to the literature by investigating the relationship between bank competition and firm credit availability using a database that matches firms to their reference bank. The structure of the data allows us to improve on the identification of the effect of bank competition on firms' financial access while simultaneously controlling for firm, bank and industry codeterminants of credit availability. We are then able to perform stringent tests of the information hypothesis by tracing the effect of bank market power across different firms and different banks. Specifically, we formulate three testable predictions based on the information hypothesis.

I Firms related to banks with high market power should have better access to credit.

II Among firms related to banks with high market power, small, risky and opaque firms should have better access to credit.

III Among banks with high market power, those with a strong interest in relationship lending should provide better access to credit to their customers.

\section{Empirical strategy}

\subsection{Bank market power: the Lerner index}

Studying the impact of bank market structure on firms' credit outcomes requires a measure of inter-bank competition. However, there is currently no consensus over the best indicator. Broadly speaking, competition metrics can be classified in two categories: structural and non-structural indicators. The former are theoretically rooted in the Structure-Conduct-Performance (SCP) view whereby bank concentration creates an environment that unfavourably affects bank conduct and performance: in other words, concentration is negatively associated with a bank's competitive conduct and favours profitability. Related empirical research commonly uses structural measures of concentration such as the Herfindahl-Hirschman-Index (HHI) or the n-firm concentration ratio to proxy for market power (Berger and Hannan, 1989; Hannan and Berger, 1991). ${ }^{4}$ Yet, recent empirical work cast doubts over the reliability of concentration as proxy of bank competition (Bikker et al., 2009) and the contestability of the banking sector. In particular, Claessens and Laeven (2004), Schaeck and Cihák (2012) and Love and Martínez Pería (2015) argue that concentration measures market structure rather than market conduct. Furthermore, structural indicators were found to lack consistency and robustness (Berger and Udell, 1995; Rhoades, 1995; Jackson, 1997; Hannan, 1997). In the attempt to remedy these shortcomings, a second category of indicators related to new Industrial Organisation (IO) methods sought to measure competition directly rather than via proxies such as market shares and market structures. These indicators include the Lerner index and the H-statistic based on the Ross-Panzar model (Panzar and Rosse, 1987).

The Lerner index measures a bank's ability to set its price above the marginal cost and provides a bank-specific measure of market power. By way of interpretation, a bank with Lerner index near zero has little market power, whereas a bank whose Lerner index is close to one is akin to a monopolist. The Lerner index presents multiple advantages over alternative metrics of market competition. First, the Lerner index is the only bank level measure of market power in addition to the bank's market share (Beck et al., 2013). While the Lerner index is a proxy for current

\footnotetext{
${ }^{4}$ The Hirschmann-Herfindahl index of concentration is the sum of the squares of the market shares (assets) of each bank in each country.
} 
and future profits deriving from pricing power, market share also captures the implicit rents extracted from being too-big-to-fail. As such, market share is subject to measurement error as a proxy for pricing power. Second,the Lerner index captures pricing power on both the asset and liability structure of the bank's balance sheet, since it calculates the differences between profits on assets and costs of funding operations (Beck et al., 2013). Third, unlike the H-statistic, estimating the Lerner index does not require a banking system to be in long run equilibrium (Schaeck and Cihák, 2012). Fourth,unlike market concentration and market shares, the Lerner index does not depend on definitions of geographic product markets (Aghion et al., 2005). This task is particularly complex for the banking industry given the extent of transnational operations. ${ }^{5}$ As our main purpose is to examine the bank-firm level relationship between competition and access to credit, we follow recent literature (Maudos and Fernndez de Guevara, 2007; Berger et al., 2009; Beck et al., 2013; Anginer et al., 2014; Fungacova et al., 2014) and use the Lerner index as our main measure of competition. Given the estimates of a bank's price and marginal cost, the Lerner index is calculated as:

$$
\text { Lerner }_{b, t}=\frac{P_{b, t}-M C_{b, t}}{P_{b, t}}
$$

where $P_{b, t}$ is proxied by total operating income over total assets. The marginal cost $\left(M C_{b, t}\right)$ is derived from a translog function as explained in appendix A. We thus obtain a Lerner index for each bank and have a direct measure of bank market power for our main analysis. In table 1 we document that aggregate Lerner indices are meaningfully and statistically related with other standard measures of inter-bank competition and market structure. Specifically, table 1 reports correlations between non-structural measures (the Hirschmann-Herfindahl index, the CR5 concentration ratio ${ }^{6}$ and bank level market shares), the Panzar-Rosse H-statistic (Panzar and Rosse, 1987) and the country average of the Lerner index previously estimated. All indicators are at the country-year level and are defined so that an increase in the metric corresponds to less competition (i.e. we take the negative of the $\mathrm{H}$-statistic). The Lerner index is positively and significantly correlated to all other measures, which further corroborates our choice of using it as measure of inter-bank competition.

\subsection{Matched firm-bank data}

We combine bank data from Orbis Bank Focus with firm data from Amadeus. ${ }^{7}$ Restricting our research to the euro area, we extract annual information on 3.650 banks and 2.056 .537 firms for the period 2010-2016. We then match banks to firms using the information on the identity of firms' reference bankers as in Amiti and Weinstein (2011). ${ }^{8}$

\footnotetext{
${ }^{5}$ Admittedly, the estimation of the cost function requires choosing the scope of the market (Beck et al., 2013). We estimate the cost function by country but as robustness check we make sure that estimating a cost function at the euro area level does not alter our results.

${ }^{6}$ This reflects the market share of the largest five banks in each country.

${ }^{7}$ Orbis Bank Focus (previously Bankscope) contains information on over 40,000 public and private banks around the world, while Amadeus contains financial information on over 24 million public and private European companies. Both databases are compiled by Bureau Van Dijk, a Moody's Analytics company.

${ }^{8}$ This corresponds to the "banker name" variable reported in Amadeus. Our procedure is akin to that of Amiti and Weinstein (2011) who use Japan's companies handbook information to match each firm to its reference lender. In our case, the main limitation is that the "banker name" variable is time-invariant: that is, bank-firm records are a snapshot of current borrowers-lending relationships and do not change over time. Since the sample period is relatively short (6 years), we regard as tenable the assumption that bank-firm relationships remain stable over this period.
} 
Table 1: Pair-wise correlations between different measures of banking concentration and competition, p-values in parentheses.

\begin{tabular}{l|llll}
\hline & Lerner & Market share & HHI & CR5 \\
\hline \hline \multirow{3}{*}{ Market share } & 0.2436 & & & \\
& $(0.0000)$ & & & \\
HHI & 0.6012 & 0.7781 & & \\
& $(0.0000)$ & $(0.0000)$ & & \\
CR5 & & & & \\
& 0.6225 & 0.6647 & 0.9811 & \\
& $(0.0000)$ & $(0.0000)$ & $(0.0000)$ & \\
-(H-statistic) & 0.7197 & -0.6994 & -0.1060 & 0.0746 \\
& $(0.0000)$ & $(0.0000)$ & $(0.0000)$ & $(0.0000)$ \\
\hline \hline
\end{tabular}

Specifically, we perform a "fuzzy merge" using bank names, country and accounts consolidation identifiers reported in each database as in Chodorow-Reich (2014). ${ }^{9}$ Furthermore, as the "banker name" variable indicates banks at the group level, we only keep banks with consolidated accounts in order to avoid mismatches. Restricting the sample to banks for which the Lerner index could be estimated yields to a final database containing 335.656 bank-firm observations: 901 banks matched to 59.023 firms (i.e. $25 \%$ and $3 \%$ of the original samples, respectively) covering 11 euro area countries for the period 2010-2016. ${ }^{10}$

While is not uncommon for European firms to deal with several lenders, most firms tend to have single-bank relationships, especially small firms (Cressy and Olofsson, 1997). In our sample less than a quarter of firms are related to more than one bank (i.e. 469.744, or $23 \%$ of the original sample). For the purpose of this paper, we consider a reference bank as the primary institution from which firms obtain most of short and long term credit and with which are likely to build lasting relationships in the sense of Petersen and Rajan (1994, 1995). Activities related to the provision of credit and monitoring allow reference banks and firms to form ties through repeated interaction over time and across multiple financial products. For instance, firms typically hold checking and savings account at their reference bank, while in turn banks also provides support for IPOs. The deep and complex dimension of bank-firm relationships facilitates the storing of information and may increase the availability of fund to the firm (Petersen and Rajan, 1994, 1995) ${ }^{11}$ Moreover, these relationships imply that banks and firms are interdependent: shocks affecting banks are likely to be reflected on customer firms, and vice versa (Chodorow-Reich, 2014; Amiti and Weinstein, 2011). In this respect, some evidence is reported in appendix B: Firms' total bank borrowing is strongly correlated to loans and key balance sheet variables of their reference bank.

\footnotetext{
${ }^{9}$ The fuzzy merge is carried out using the Stata ado file reclink2 written by Micheal Blasnik which uses a bigram string comparator to calculate the fraction of consecutive character matches between two string variables (banker name). To ensure accuracy, we also perform a clerical review of all matches.

${ }^{10}$ Many observations are lost as the "banker name" variable was not available for Italy, Belgium, Finland, Slovakia and Luxembourg. Further observations on firm-bank pairs are lost since the Lerner index cannot be estimated for Greek, Estonian and Lithuanian banks. The remaining countries are Austria, Cyprus, France, Germany, Ireland, Latvia, Malta, Netherlands, Portugal, Slovenia and Spain).

${ }^{11}$ For instance, by monitoring cash flows through its checking account the bank can learn about the firm's sales. In addition, the bank reaches cost efficiencies by spreading the fixed costs related to producing information over multiple products (Petersen and Rajan, 1995).
} 


\subsection{Identification and econometric model}

Testing how bank competition affects credit availability runs into identification issues. Indeed, firms' credit conditions are usually affected by factors unrelated to the level of inter-bank competition. However, most of them - industry demand, factor endowments and prices, business cycle - can be thought of as common to all firms within an industry at a given moment in time. Additionally, as noted by Bonaccorsi di Patti and Dell'ariccia (2004), firms within the same industry are likely to share a similar degree of asymmetric information stemming from the characteristics of the technology prevailing in that particular sector.

Following Amiti and Weinstein (2011), we exploit the fact that some firms are linked to banks with higher market power than other firms within the same industry in the same year. Hence, we use industry-year fixed effects to sweep out all supply-and-demand shocks and information issues shared by all firms within an industry in a given year, thus identifying how a firm's credit availability is affected by the market power of its main lender. Specifically, we estimate the following model:

$$
\ln \left(y_{f, t}\right)=\alpha_{i, t}+\text { Lerner }_{b, t-1}\left(\beta_{1}+\beta_{2} X_{f, t-1}+\beta_{3} Z_{b, t-1}\right)+\gamma_{1} X_{f, t-1}+\gamma_{2} Z_{b, t-1}+\gamma_{3} Y_{f, b, t}+\varepsilon_{f, b, t}
$$

where $y_{f, t}$ is a firm level outcome variable measuring access to credit, $f$ indicates firms, $b$ banks, $i$ industries and $t$ years. Specifically, we use NAICSE codes to identify industrial sectors. We use two quantitative measures for credit availability: bank credit and trade credit. ${ }^{12}$ The first measure corresponds to the amount of credit a firm receives by banks in any given year and is a direct indicator funds lent by financial intermediaries. Admittedly, this variable is the sum of all loans obtained from different banks and unfortunately we have no information on the exact share lent by each bank. We therefore work under the assumption that the reference bank provides the largest share of loans and that this variable effectively captures the intensive margin of the credit relationship. Available evidence supports this assumption: For instance, Cressy and Olofsson (1997) note that the main sources of finance for European SMEs are retained earnings, trade credit and credit from a single bank, while Petersen and Rajan (1994) report that US SMEs obtain between $75 \%$ and $95 \%$ of their loans from their main bank. Considering the bank-based nature of Europe corporate finance and the relative scarcity of non-bank alternatives for SMEs, these figures are likely under-estimates in the European context. We also provide in-sample evidence showing that firms' bank credit is closely related to their reference bank's total loans (see appendix B).

Still, measuring credit availability directly is problematic. Since bank credit is jointly determined by supply and demand, regressing firms' bank credit on bank market power may lead to simultaneity bias if bank market power affects both the supply of and demand for bank lending (Petersen and Rajan, 1994, 1995). However, since using industry-year fixed effects already absorbs all sector-specific cyclical demand for credit, this concern should be less severe in our set up. ${ }^{13}$ Nonetheless, we use trade credit as a second proxy for credit availability in order to corroborate our findings. The idea is as follows: In order to finance new investment, credit rationed firms

\footnotetext{
${ }^{12}$ The main reason to focus on the quantity rather than price of credit is that theoretical predictions on the impact of relationship-lending on interest rates are ambiguous. Conversely, the information hypothesis unequivocally foresees that the availability of funds for a firm should increase as a result of bank-firm relationships (Petersen and Rajan, 1994).

${ }^{13}$ Simultaneity bias may apply only insofar credit demand at the firm level is systematically associated to its reference bank's market power, i.e. if firms associated to banks with high market power demand systematically more (or less) credit.
} 
will turn to more expensive sources of finance, whereas firms with access to bank credit are less likely to recur to more expensive sources. The credit borrowed from more expensive sources should then capture the extent to which firms are supply constrained by banks (Petersen and Rajan, 1994, 1995; Nilsen, 2002; Carbo Valverde et al., 2009). ${ }^{14}$ Specifically, in our exercise we will compare trade credit to short-term bank credit since they are likely to be direct substitutes. ${ }^{15}$

Recent research cast doubts on the reliability of trade credit as proxy for financing constraint by emphasising the informational content of trade credit (Giannetti et al., 2011; Agostino and Trivieri, 2014). Specifically, trade credit may send a positive signal to banks on the creditworthiness of potential borrowers, in turn making banks less reluctant to lend. In this sense, rather than a substitute, trade credit may be seen as a complement to bank lending. However, since this signalling should be especially valuable for relatively uninformed banks that do not dispose of soft information on firms, we regard this specific concern to be less relevant in our analysis for it focuses on banks that are already in a lending relationship and are therefore unlikely to be uninformed.

The main dependent variable is the banks' Lerner index discussed in section 2.1. Vectors $X$ and $Z$ contain, respectively, firm and bank level control variables. As in Beck et al. (2013) the Lerner index and all firm and bank level variables enter the model with a lag to mitigate endogeneity concerns related to potential reverse causality. Vector $Y$ contains country level variables such as real GDP growth and inflation. The interaction terms are designed to capture how the effect of bank market power on credit availability varies across firms and banks. Finally, industry-year fixed effects $\left(\alpha_{i, t}\right)$ are included to absorb all time-varying industry-specific shocks.

Model (1) allows testing the theoretical predictions outlined in section 1. First, for the information hypothesis, higher bank market power should increase the benefits of relationship lending and hence increase credit availability for all firms across the board. Accordingly, one would expect $\beta_{1}$ to be positive (negative) when $y_{f, t}$ is bank credit (trade credit). Second, for the information hypothesis, by increasing the incentive to engage in relationship lending, higher bank market power (i.e. an increase in the Lerner index) should increase credit availability especially for small, risky and opaque firms. The coefficient $\beta_{2}$ is then expected to be positive (negative) when $y_{f, t}$ is bank credit (trade credit). Third, for the information hypothesis, firms whose reference bank has a comparative advantage or is specialised in relationship lending (small and local cooperative banks) and firms with a single reference bank should benefit relatively more of lower levels of inter-bank competition. Accordingly, the coefficient $\beta_{3}$ is expected to be positive (negative) when $y_{f, t}$ is bank credit (trade credit).

\footnotetext{
${ }^{14}$ Trade credit is a short-term loan a supplier provides to customers in concurrence with the sale of his products (Nilsen, 2002) and it typically is an inferior substitute to bank loans for a number of reasons: first, unlike bank loans trade credit is intrinsically linked to the purchase of goods; second, while bank loans are long-term, trade credit is usually very short-term (30 days in the US according to Nilsen (2002)); third, given the supplier is not necessarily a financier, the customer faces significant late payment penalties (both explicitly pecuniary as well as implicit such as the cost of damaging a long-term relationship (Petersen and Rajan, 1994)). Therefore, while trade credit is available to most firms, they usually prefer bank loans given the former's unattractiveness. For instance, Petersen and Rajan (1994) calculates that foregoing trade credit early discount correspond to an annualised borrowing rate of $44.6 \%$.

${ }^{15}$ In studying how bank market power affects credit availability by contrasting bank and trade credit, we also make the implicit assumption that the market power of suppliers providing trade credit is industry specific. This is supported by the observation that discount terms in trade credit contracts are typically set at the industry level (Dun and Breadstreet, 1970; Ellienhausen and Wolken, 1993). Hence, as noted by Petersen and Rajan (1994), using industry dummies will also control for differences in terms and conditions for trade credit financing across industries.
} 


\section{Results}

This section presents the main results. We first focus on the overall effect of bank market power on firms' access to credit and then look at how this relationship varies across firms and banks.

\subsection{The effect of bank market power on firms' access to credit}

Estimates on the overall impact of bank competition on firm's access to credit are reported in table 2. Specifically, we estimate model (1) with industry-year fixed effects and cluster standard errors at the firm level. We test here the first theoretical predictions outlined in section 1: for the information hypothesis, higher bank market power should be related to higher credit availability for customer firms. The test therefore rests on the sign and statistical significance of $\beta_{1}$.

Results strongly reject the information hypothesis. Columns 1 and 7 shows that banks' Lerner index is positively related to trade credit and negatively related to short-term bank credit. In other words, firms whose reference banks enjoy high market power have on average more trade credit and less short-term bank credit, consistent with the notion that market power has a negative effect on credit availability.

The robustness of this result is checked across different specifications. In columns 2 and 8 we add firm level variables in order to control for firm balance sheet characteristics that may explain some of the cross-firm variation in credit availability. First, the log of firm sales complements the $\log$ of firm total assets in capturing firm size and is included since a firm's financing patterns vary widely with size (Beck et al., 2008, 2013). ${ }^{16}$ Second, firm cash flows and profitability (the ratio of profit before taxes over total assets) are added as observable measures of firm performance and quality (Carbo Valverde et al., 2009). Third, firm default risk is defined as the ratio of operating profits to interest paid. As noted by Carbo Valverde et al. (2009) this variable captures operating risk by showing how many times interest paid are covered by operating profits. Fourth, firm transparency is defined as the ratio of tangible fixed assets over total assets and measures the extent to which a firm can post tangible collateral to obtain external financing (Bonaccorsi di Patti and Dell'ariccia, 2004; Freixas and Rochet, 2008; Fungáčová et al., 2014).

Similarly, in columns 3 and 9 we add bank-level variables to capture bank balance sheet characteristics that are traditionally considered as determinants of credit supply. First, bank credit risk is defined as non-performing loans over loans and control for the (ex-post) quality of banks' loan portfolios (Carbo Valverde et al., 2009). Second, bank profitability, measured by return on assets, stands to capture any linkage between bank performance and credit supply (Carbo Valverde et al., 2009). Third, bank risk is measured as the log of the Z-score (Beck et al., 2013) and measures a bank's distance from insolvency (Roy, 1952).

In columns 4 and 10 we introduce additional macroeconomic variables to control for general economic (Real log GDP) and financial conditions (sovereign spread) at the country level. Next, in columns 5 and 11 we replace the NAICSE industrial code with the NACE industry definition as in Ryan et al. (2014a). ${ }^{17}$ Finally, as discussed in section 2.1, we re-estimate the model using a Lerner index calculated from a euro area level cost function (rather than country by country) and report estimates in columns 6 and 12.

\footnotetext{
${ }^{16}$ For instance, large firms may benefit from internal capital market and thus face minor financial constraint (Carbo Valverde et al., 2009).

${ }^{17}$ According to Ryan et al. (2014a), NACE codes are the narrowest available definition of industrial sectors under the official Statistical Classification of Economic Activities in the European Community.
} 
Table 2: General effect of market power on firms' credit availability

\begin{tabular}{|c|c|c|c|c|c|c|c|c|c|c|c|c|}
\hline VARIABLES & (1) & (2) & $\begin{array}{l}(3) \\
\ln \text { (Trade }\end{array}$ & $\begin{array}{c}(4) \\
\text { Credit) } \\
f, t\end{array}$ & (5) & (6) & (7) & (8) & $\begin{array}{c}\text { (9) } \\
\ln \text { (Short-Tern } \\
\end{array}$ & $\begin{array}{c}(10) \\
\text { Bank Credit) }\end{array}$ & $\begin{array}{l}\text { (11) } \\
\end{array}$ & (12) \\
\hline Lerner $_{b, t-1}$ & $\begin{array}{l}0.477^{* * *} \\
(0.0937)\end{array}$ & $\begin{array}{l}0.575^{* * *} \\
(0.0987)\end{array}$ & $\begin{array}{c}0.685^{* * *} \\
(0.177)\end{array}$ & $\begin{array}{c}0.792^{* * *} \\
(0.170)\end{array}$ & $\begin{array}{c}0.831^{* * *} \\
(0.172)\end{array}$ & $\begin{array}{c}0.868^{* * *} \\
(0.140)\end{array}$ & $\begin{array}{c}-2.246^{* * *} \\
(0.200)\end{array}$ & $\begin{array}{c}-1.608^{* * *} \\
(0.231)\end{array}$ & $\begin{array}{l}-1.581^{* * *} \\
(0.381)\end{array}$ & $\begin{array}{c}-1.101^{* * *} \\
(0.374)\end{array}$ & $\begin{array}{c}-1.014^{* * *} \\
(0.385)\end{array}$ & $\begin{array}{c}-1.104^{* * *} \\
(0.365)\end{array}$ \\
\hline $\ln (\text { total assets })_{f, t-1}$ & $\begin{array}{l}0.893^{* * *} \\
(0.0146)\end{array}$ & $\begin{array}{l}0.395^{* * *} \\
(0.0304)\end{array}$ & $\begin{array}{l}0.439^{* * *} \\
(0.0323)\end{array}$ & $\begin{array}{l}0.386^{* * *} \\
(0.0341)\end{array}$ & $\begin{array}{l}0.355^{* \star *} \\
(0.0357)\end{array}$ & $\begin{array}{l}0.380^{* * *} \\
(0.0300)\end{array}$ & $\begin{array}{l}0.995^{* * *} \\
(0.0271)\end{array}$ & $\begin{array}{l}0.957^{* * *} \\
(0.0560)\end{array}$ & $\begin{array}{l}0.937^{* * *} \\
(0.0585)\end{array}$ & $\begin{array}{l}0.813^{* * *} \\
(0.0605)\end{array}$ & $\begin{array}{l}0.787^{* * *} \\
(0.0630)\end{array}$ & $\begin{array}{l}0.815^{* * *} \\
(0.0531)\end{array}$ \\
\hline $\ln (\text { sales })_{f, t-1}$ & & $\begin{array}{l}0.666^{* * *} \\
(0.0327)\end{array}$ & $\begin{array}{l}0.664^{* * *} \\
(0.0357)\end{array}$ & $\begin{array}{l}0.728^{* * *} \\
(0.0388)\end{array}$ & $\begin{array}{l}0.770^{* * *} \\
(0.0390)\end{array}$ & $\begin{array}{l}0.661^{* * *} \\
(0.0323)\end{array}$ & & $\begin{array}{l}0.143^{* * *} \\
(0.0544)\end{array}$ & $\begin{array}{l}0.141^{* *} \\
(0.0594)\end{array}$ & $\begin{array}{l}0.276^{* * *} \\
(0.0602)\end{array}$ & $\begin{array}{l}0.299^{* * *} \\
(0.0644)\end{array}$ & $\begin{array}{l}0.291^{* * *} \\
(0.0531)\end{array}$ \\
\hline $\ln (\text { cash flow })_{f, t-1}$ & & $\begin{array}{c}-0.0737^{* * *} \\
(0.0219)\end{array}$ & $\begin{array}{c}-0.0741^{* * *} \\
(0.0237)\end{array}$ & $\begin{array}{l}-0.0538^{* *} \\
(0.0240)\end{array}$ & $\begin{array}{c}-0.0658^{* * *} \\
(0.0249)\end{array}$ & $\begin{array}{l}-0.0401^{*} \\
(0.0218)\end{array}$ & & $\begin{array}{l}-0.0931^{*} \\
(0.0489)\end{array}$ & $\begin{array}{l}-0.0774 \\
(0.0511)\end{array}$ & $\begin{array}{l}-0.0315 \\
(0.0508)\end{array}$ & $\begin{array}{l}-0.0335 \\
(0.0526)\end{array}$ & $\begin{array}{l}-0.0470 \\
(0.0447)\end{array}$ \\
\hline Profit margin $_{f, t-1}$ & & $\begin{array}{c}-1.263^{* * *} \\
(0.319)\end{array}$ & $\begin{array}{c}-1.348^{* * *} \\
(0.338)\end{array}$ & $\begin{array}{l}-1.386^{* * *} \\
(0.343)\end{array}$ & $\begin{array}{c}-1.294^{* * *} \\
(0.358)\end{array}$ & $\begin{array}{c}-1.576^{* * *} \\
(0.310)\end{array}$ & & $\begin{array}{l}-0.925^{*} \\
(0.480)\end{array}$ & $\begin{array}{l}-0.805 \\
(0.562)\end{array}$ & $\begin{array}{l}-0.967^{*} \\
(0.568)\end{array}$ & $\begin{array}{l}-0.941 \\
(0.585)\end{array}$ & $\begin{array}{l}-1.115^{* *} \\
(0.501)\end{array}$ \\
\hline Default risk $_{f, t-1}$ & & $\begin{array}{l}-0.0174 \\
(0.0117)\end{array}$ & $\begin{array}{l}-0.0210^{*} \\
(0.0121)\end{array}$ & $\begin{array}{l}-0.0259^{* *} \\
(0.0119)\end{array}$ & $\begin{array}{l}-0.0233^{*} \\
(0.0124)\end{array}$ & $\begin{array}{c}-0.0129 \\
(0.00915)\end{array}$ & & $\begin{array}{c}-0.393^{* * *} \\
(0.0402)\end{array}$ & $\begin{array}{c}-0.385^{* * *} \\
(0.0389)\end{array}$ & $\begin{array}{c}-0.394^{* * *} \\
(0.0395)\end{array}$ & $\begin{array}{c}-0.398^{* * *} \\
(0.0401)\end{array}$ & $\begin{array}{c}-0.269^{* * *} \\
(0.0275)\end{array}$ \\
\hline $\operatorname{Transparency}_{f, t-1}$ & & $\begin{array}{l}-0.268^{* *} \\
(0.105)\end{array}$ & $\begin{array}{c}-0.411^{* * *} \\
(0.113)\end{array}$ & $\begin{array}{c}-0.456^{* * *} \\
(0.114)\end{array}$ & $\begin{array}{c}-0.430^{* * *} \\
(0.119)\end{array}$ & $\begin{array}{c}-0.582^{* * *} \\
(0.0947)\end{array}$ & & $\begin{array}{c}1.339^{* \star *} \\
(0.170)\end{array}$ & $\begin{array}{c}1.100^{* * *} \\
(0.176)\end{array}$ & $\begin{array}{c}0.964^{* * *} \\
(0.176)\end{array}$ & $\begin{array}{l}1.005^{* * *} \\
(0.180)\end{array}$ & $\begin{array}{c}1.061^{* * *} \\
(0.152)\end{array}$ \\
\hline $\ln (\text { total assets })_{b, t-1}$ & & & $\begin{array}{l}-0.0139 \\
(0.0215)\end{array}$ & $\begin{array}{l}-0.0489^{* *} \\
(0.0213)\end{array}$ & $\begin{array}{c}-0.0586^{* * *} \\
(0.0218)\end{array}$ & $\begin{array}{l}-0.0157 \\
(0.0150)\end{array}$ & & & $\begin{array}{l}0.0843^{*} \\
(0.0448)\end{array}$ & $\begin{array}{c}0.0143 \\
(0.0451)\end{array}$ & $\begin{array}{l}0.00940 \\
(0.0463)\end{array}$ & $\begin{array}{c}-0.0802^{* *} \\
(0.0361)\end{array}$ \\
\hline NPL ratio $b, t-1$ & & & $\begin{array}{l}1.675^{* *} \\
(0.755)\end{array}$ & $\begin{array}{c}0.995 \\
(0.666)\end{array}$ & $\begin{array}{l}1.155^{*} \\
(0.683)\end{array}$ & $\begin{array}{l}-0.0295 \\
(0.212)\end{array}$ & & & $\begin{array}{l}1.752 \\
(1.636)\end{array}$ & $\begin{array}{c}0.325 \\
(1.588)\end{array}$ & $\begin{array}{c}0.939 \\
(1.633)\end{array}$ & $\begin{array}{l}-0.209 \\
(0.536)\end{array}$ \\
\hline $\mathrm{ROA}_{b, t-1}$ & & & $\begin{array}{c}-7.929^{* *} \\
(3.767)\end{array}$ & $\begin{array}{l}-1.555 \\
(2.451)\end{array}$ & $\begin{array}{l}-1.866 \\
(2.579)\end{array}$ & $\begin{array}{l}3.671^{*} \\
(1.906)\end{array}$ & & & $\begin{array}{l}-19.23^{* *} \\
(7.465)\end{array}$ & $\begin{array}{c}7.866 \\
(6.645)\end{array}$ & $\begin{array}{c}7.099 \\
(6.195)\end{array}$ & $\begin{array}{l}-2.221 \\
(5.486)\end{array}$ \\
\hline $\ln (\mathrm{Z} \text { scores })_{b, t-1}$ & & & $\begin{array}{c}0.914 \\
(0.676)\end{array}$ & $\begin{array}{l}1.679^{* *} \\
(0.686)\end{array}$ & $\begin{array}{l}1.782^{* * *} \\
(0.668)\end{array}$ & $\begin{array}{c}2.954^{* * *} \\
(0.736)\end{array}$ & & & $\begin{array}{c}1.099 \\
(0.801)\end{array}$ & $\begin{array}{c}0.816 \\
(1.308)\end{array}$ & $\begin{array}{c}0.984 \\
(1.369)\end{array}$ & $\begin{array}{l}-0.335 \\
(1.301)\end{array}$ \\
\hline Real GDP growth $f b, t$ & $\begin{array}{c}-19.30^{* * *} \\
(3.123)\end{array}$ & $\begin{array}{c}-25.83^{* * *} \\
(4.034)\end{array}$ & $\begin{array}{c}-27.19^{* * *} \\
(6.237)\end{array}$ & $\begin{array}{l}-24.26^{* * *} \\
(5.611)\end{array}$ & $\begin{array}{c}-25.67^{* * *} \\
(5.929)\end{array}$ & $\begin{array}{c}-11.84^{* * *} \\
(4.327)\end{array}$ & $\begin{array}{l}-7.702 \\
(5.772)\end{array}$ & $\begin{array}{l}-2.326 \\
(6.994)\end{array}$ & $\begin{array}{l}29.45^{* * *} \\
(10.36)\end{array}$ & $\begin{array}{c}37.69^{* * * *} \\
(9.783)\end{array}$ & $\begin{array}{c}34.38^{* * *} \\
(10.34)\end{array}$ & $\begin{array}{l}18.09^{* *} \\
(7.037)\end{array}$ \\
\hline Inflation $_{f b, t}$ & $\begin{array}{l}0.00969 \\
(0.0336)\end{array}$ & $\begin{array}{c}-0.275^{\star * *} \\
(0.0384)\end{array}$ & $\begin{array}{l}-0.217^{\star * \star} \\
(0.0496)\end{array}$ & $\begin{array}{l}0.227^{*} \\
(0.129)\end{array}$ & $\begin{array}{l}0.245^{*} \\
(0.134)\end{array}$ & $\begin{array}{c}0.0280 \\
(0.0429)\end{array}$ & $\begin{array}{l}-0.121^{*} \\
(0.0633)\end{array}$ & $\begin{array}{c}-0.303^{\text {*** }}(0.0746)\end{array}$ & $\begin{array}{l}-0.455^{* \star *} \\
(0.0886)\end{array}$ & $\begin{array}{c}-0.0619 \\
(0.273)\end{array}$ & $\begin{array}{l}-0.0344 \\
(0.267)\end{array}$ & $\begin{array}{c}-0.0428 \\
(0.0736)\end{array}$ \\
\hline $\ln (\text { Real GDP })_{f b, t}$ & & & & $\begin{array}{c}0.178 \\
(0.205)\end{array}$ & $\begin{array}{c}0.161 \\
(0.215)\end{array}$ & $\begin{array}{c}-0.323^{* * *} \\
(0.0339)\end{array}$ & & & & $\begin{array}{l}-0.485 \\
(0.393)\end{array}$ & $\begin{array}{l}-0.397 \\
(0.390)\end{array}$ & $\begin{array}{c}-0.000498 \\
(0.0540)\end{array}$ \\
\hline Sovereign spread $_{f b, t}$ & & & & $\begin{array}{l}49.04^{*} \\
(28.35)\end{array}$ & $\begin{array}{l}49.34^{*} \\
(29.66)\end{array}$ & $\begin{array}{c}-16.03^{* * *} \\
(4.498)\end{array}$ & & & & $\begin{array}{l}-7.736 \\
(54.41)\end{array}$ & $\begin{array}{c}4.999 \\
(53.88)\end{array}$ & $\begin{array}{c}47.92^{* * *} \\
(7.979)\end{array}$ \\
\hline Observations & 15,086 & 8,698 & 7,355 & 7,069 & 6,852 & 8,226 & 11,720 & 7,045 & 5,991 & 5,754 & 5,563 & 6,701 \\
\hline R-squared & 0.546 & 0.701 & 0.714 & 0.718 & 0.737 & 0.709 & 0.425 & 0.500 & 0.490 & 0.503 & 0.532 & 0.481 \\
\hline Industry $\times$ Year FE & Yes & Yes & Yes & Yes & Yes & Yes & Yes & Yes & Yes & Yes & Yes & Yes \\
\hline
\end{tabular}


Across all specifications, results reported in table 2 are qualitatively and quantitatively consistent: greater bank market power is related to higher trade credit and lower short-term bank credit for customer firms. The result is economically significant: For the full specification (columns 3 and 9), semi-elasticities indicate that a one standard deviation increase in banks' Lerner index (i.e. 0.17 , e.g. a move from the $25^{\text {th }}$ to the $75^{\text {th }}$ percentile of banks' Lerner indexes) is associated to a $12 \%$ increase in trade credit and to a $27 \%$ decrease in short-term bank credit by customer firms over the following year. Moreover, the finding that the Lerner index has the opposite effect on trade and bank credit suggests that higher bank market power leads to credit rationing and pushes customer firms toward alternative sources of finance.

\subsection{The effect of bank market power across firms}

In this section we investigate how bank market power affects financial constraint across firms to test the second theoretical predictions outlined in section 1: For the information hypothesis we would expect small, lower quality and opaque firms linked to banks with higher market power to enjoy better access to credit relative to large, high quality and transparent firms. This test therefore hinges on estimates of $\beta_{2}$ as modelled in (1). Estimates are reported in table 3 and graphed in figure 1. First, we investigate firm size and use both a continuous variable - the natural $\log$ of total assets - and a dummy variable for small and medium-sized enterprises (SMEs). ${ }^{18}$

Columns 1 and 7 in table 3 indicate that SMEs serviced by banks with higher bank market obtain less short-term bank credit and increase trade credit by less than larger firms. Similarly, estimates in columns 2 and 8 report that the negative effect of bank market power on short-term bank credit weakens with firm size, while this is not significant for trade credit. Specifically, the reduction in short term bank credit associated with a one standard deviation increase in banks' Lerner is $58 \%$ for a small firm (at the $25^{\text {th }}$ percentile by size) and $31 \%$ for a large firm (at the $75^{\text {th }}$ percentile). We interpret these as suggestive that higher bank market power leads to more severe credit rationing for small firms, which in turn find it more difficult to fully replace the reduction in bank credit with trade credit. This evidence is consistent with Beck et al. (2004) and the wellestablished notion that small firms are more bank-dependent and more vulnerable to information problems than large firms. Indeed, information asymmetries are thought to be particularly strong for small firms because of their restricted credit history and track record, and because of their lower ability to provide collateral. Conversely, large firms may benefit from internal capital market and may face less financing constraints (Carbo Valverde et al., 2009; Andrieu et al., 2018).

Second, according to the information hypothesis, banks should lend more to lower quality firms in more concentrated markets (Petersen and Rajan, 1995). We find mixed evidence but overall contradicting evidence with respect to this theoretical prediction. Estimates in columns 3,4,5 and 9,10,11 indicate that firms with high cash flows buffer the negative effect of higher bank market power: they recur less to trade credit and have a lower reduction in short-term bank lending. Similarly, for a given level of bank market power, high profit firms recur to less trade credit but their bank credit is no less restricted than other firms. Viewed comparatively, a one standard deviation increase in banks' Lerner is associated to a $43 \%$ drop in short-term bank credit and a $8 \%$ increase in trade credit for a low quality firm ( $10^{\text {th }}$ percentile by cash flow $)$ as opposed to a $28 \%$ drop in bank credit and a $4 \%$ increase in trade for a high quality firm ( $75^{\text {th }}$ percentile). Finally, there are no significant differential effects for high default risk firms.

\footnotetext{
${ }^{18}$ This is based on the definition of Small and Medium Enterprises by the European Union. A firm is considered a SME if it has (i) 250 or less employees or (ii) operating revenue in excess of EUR 50 million and total assets in excess of EUR 43 million.
} 
Table 3: Effect of market power on firms' credit availability across firms

\begin{tabular}{|c|c|c|c|c|c|c|c|c|c|c|c|c|}
\hline \multirow[b]{2}{*}{ VARIABLES } & \multirow[t]{2}{*}{ (1) } & \multirow[t]{2}{*}{ (2) } & \multirow{2}{*}{\multicolumn{2}{|c|}{$\begin{array}{c}(3) \\
\ln (\text { Trade Credit) } \\
f, t\end{array}$}} & \multirow[t]{2}{*}{ (5) } & \multirow[t]{2}{*}{ (6) } & \multirow[t]{2}{*}{ (7) } & \multirow{2}{*}{\multicolumn{4}{|c|}{$\begin{array}{ccc}(8) & (9) & (10) \\
& \ln (\text { Short-Term Bank Credit) } \\
f, t & \\
\end{array}$}} & \multirow{2}{*}{$(12)$} \\
\hline & & & & & & & & & & & & \\
\hline Lerner $_{b, t-1}$ & $\begin{array}{c}1.166^{* * *} \\
(0.180)\end{array}$ & $\begin{array}{l}0.266^{*} \\
(0.150)\end{array}$ & $\begin{array}{l}0.254^{*} \\
(0.130)\end{array}$ & $\begin{array}{l}0.505^{* * *} \\
(0.131)\end{array}$ & $\begin{array}{c}0.318^{* * *} \\
(0.115)\end{array}$ & $\begin{array}{c}0.580^{* * *} \\
(0.161)\end{array}$ & $\begin{array}{c}-0.774^{* *} \\
(0.372)\end{array}$ & $\begin{array}{c}-2.653^{* * *} \\
(0.292)\end{array}$ & $\begin{array}{c}-1.491^{* * *} \\
(0.265)\end{array}$ & $\begin{array}{c}-1.772^{* * *} \\
(0.247)\end{array}$ & $\begin{array}{c}-1.752^{\star * *} \\
(0.224)\end{array}$ & $\begin{array}{c}-3.086^{* * *} \\
(0.349)\end{array}$ \\
\hline Lerner $_{b, t-1} \times \mathrm{SME}_{f}$ & $\begin{array}{c}-0.871^{* * *} \\
(0.157)\end{array}$ & & & & & & $\begin{array}{c}-1.070^{* * *} \\
(0.324)\end{array}$ & & & & & \\
\hline $\begin{array}{l}\text { Lerner }_{b, t-1} \\
\times \ln (\text { total assets })_{f, t-1}\end{array}$ & & $\begin{array}{c}0.0530 \\
(0.0701)\end{array}$ & & & & & & $\begin{array}{c}0.512^{* * *} \\
(0.144)\end{array}$ & & & & \\
\hline $\begin{array}{l}\text { Lerner }_{b, t-1} \\
\times \ln \left(\text { cash flow }_{f, t-1}\right.\end{array}$ & & & $\begin{array}{l}-0.0976^{*} \\
(0.0559)\end{array}$ & & & & & & $\begin{array}{c}0.280^{* * *} \\
(0.108)\end{array}$ & & & \\
\hline $\begin{array}{l}\text { Lerner }_{b, t-1} \\
\times \text { Profit margin }_{f, t-1}\end{array}$ & & & & $\begin{array}{l}-3.141^{* *} \\
(1.530)\end{array}$ & & & & & & $\begin{array}{l}0.0170 \\
(2.001)\end{array}$ & & \\
\hline $\begin{array}{l}\text { Lerner }_{b, t-1} \\
\times \text { Default risk }_{f, t-1}\end{array}$ & & & & & $\begin{array}{c}0.105 \\
(0.0721)\end{array}$ & & & & & & $\begin{array}{r}-0.0998 \\
(0.262)\end{array}$ & \\
\hline $\begin{array}{l}\text { Lerner }_{b, t-1} \\
\times \text { Transparency }_{f, t-1}\end{array}$ & & & & & & $\begin{array}{l}-1.010^{* *} \\
(0.485)\end{array}$ & & & & & & $\begin{array}{c}5.448^{* * *} \\
(0.845)\end{array}$ \\
\hline $\ln (\text { Total assets })_{f, t-1}$ & $\begin{array}{l}0.732^{* * *} \\
(0.0262)\end{array}$ & $\begin{array}{l}0.720^{* * *} \\
(0.0460)\end{array}$ & $\begin{array}{l}0.749^{* * *} \\
(0.0259)\end{array}$ & $\begin{array}{l}0.746^{* * *} \\
(0.0257)\end{array}$ & $\begin{array}{l}0.747^{* * *} \\
(0.0259)\end{array}$ & $\begin{array}{l}0.747^{* * *} \\
(0.0259)\end{array}$ & $\begin{array}{l}1.046^{* * *} \\
(0.0488)\end{array}$ & $\begin{array}{l}0.808^{* * *} \\
(0.0876)\end{array}$ & $\begin{array}{l}1.054^{* * *} \\
(0.0483)\end{array}$ & $\begin{array}{l}1.065^{* * *} \\
(0.0485)\end{array}$ & $\begin{array}{l}1.065^{* * *} \\
(0.0484)\end{array}$ & $\begin{array}{l}1.055^{* * *} \\
(0.0484)\end{array}$ \\
\hline $\ln (\text { Cash flow })_{f, t-1}$ & $\begin{array}{l}0.195^{* * *} \\
(0.0222)\end{array}$ & $\begin{array}{l}0.209^{\star \star *} \\
(0.0226)\end{array}$ & $\begin{array}{l}0.248^{* \star *} \\
(0.0348)\end{array}$ & $\begin{array}{l}0.208^{* * *} \\
(0.0222)\end{array}$ & $\begin{array}{l}0.207^{* * *} \\
(0.0225)\end{array}$ & $\begin{array}{l}0.207^{* * *} \\
(0.0224)\end{array}$ & $\begin{array}{l}-0.0768^{*} \\
(0.0396)\end{array}$ & $\begin{array}{l}-0.0478 \\
(0.0401)\end{array}$ & $\begin{array}{c}-0.181^{* * *} \\
(0.0646)\end{array}$ & $\begin{array}{l}-0.0635 \\
(0.0401)\end{array}$ & $\begin{array}{l}-0.0638 \\
(0.0399)\end{array}$ & $\begin{array}{l}-0.0541 \\
(0.0401)\end{array}$ \\
\hline Profit $\operatorname{margin}_{f, t-1}$ & $\begin{array}{c}-3.157^{* * *} \\
(0.326)\end{array}$ & $\begin{array}{c}-3.220^{* * *} \\
(0.330)\end{array}$ & $\begin{array}{c}-3.176^{* * *} \\
(0.328)\end{array}$ & $\begin{array}{l}-1.776^{* *} \\
(0.827)\end{array}$ & $\begin{array}{c}-3.197^{* * *} \\
(0.328)\end{array}$ & $\begin{array}{c}-3.202^{* * *} \\
(0.326)\end{array}$ & $\begin{array}{l}-0.417 \\
(0.341)\end{array}$ & $\begin{array}{l}-0.562^{*} \\
(0.341)\end{array}$ & $\begin{array}{l}-0.532 \\
(0.340)\end{array}$ & $\begin{array}{l}-0.466 \\
(0.909)\end{array}$ & $\begin{array}{l}-0.465 \\
(0.343)\end{array}$ & $\begin{array}{l}-0.512 \\
(0.342)\end{array}$ \\
\hline Default risk $_{f, t-1}$ & $\begin{array}{c}-0.0392^{* * *} \\
(0.0131)\end{array}$ & $\begin{array}{c}-0.0404^{* * *} \\
(0.0130)\end{array}$ & $\begin{array}{c}-0.0384^{* * *} \\
(0.0130)\end{array}$ & $\begin{array}{c}-0.0369^{* * *} \\
(0.0130)\end{array}$ & $\begin{array}{c}-0.0980^{* *} \\
(0.0457)\end{array}$ & $\begin{array}{c}-0.0421^{* * *} \\
(0.0131)\end{array}$ & $\begin{array}{c}-0.404^{* * *} \\
(0.0394)\end{array}$ & $\begin{array}{c}-0.407^{* * *} \\
(0.0397)\end{array}$ & $\begin{array}{c}-0.412^{* * *} \\
(0.0399)\end{array}$ & $\begin{array}{c}-0.405^{* * *} \\
(0.0398)\end{array}$ & $\begin{array}{c}-0.347^{\star *} \\
(0.164)\end{array}$ & $\begin{array}{c}-0.392^{* * *} \\
(0.0391)\end{array}$ \\
\hline $\operatorname{Transparency~} f, t-1_{1}$ & $\begin{array}{c}-0.966^{* * *} \\
(0.113)\end{array}$ & $\begin{array}{c}-0.974^{* * *} \\
(0.114)\end{array}$ & $\begin{array}{c}-0.969^{* * *} \\
(0.114)\end{array}$ & $\begin{array}{c}-0.981^{* * *} \\
(0.112)\end{array}$ & $\begin{array}{c}-0.976^{* * *} \\
(0.114)\end{array}$ & $\begin{array}{c}-0.542^{* *} \\
(0.269)\end{array}$ & $\begin{array}{c}1.282^{* * *} \\
(0.168)\end{array}$ & $\begin{array}{c}1.258^{* * *} \\
(0.166)\end{array}$ & $\begin{array}{c}1.272^{* * *} \\
(0.168)\end{array}$ & $\begin{array}{c}1.272^{* * *} \\
(0.168)\end{array}$ & $\begin{array}{l}1.273^{* * *} \\
(0.168)\end{array}$ & $\begin{array}{c}-1.068^{* *} \\
(0.428)\end{array}$ \\
\hline Real GDP growth $b f, t$ & $\begin{array}{c}-20.82^{* * *} \\
(4.302)\end{array}$ & $\begin{array}{c}-20.37^{\star \star *} \\
(4.326)\end{array}$ & $\begin{array}{c}-20.07^{* * *} \\
(4.324)\end{array}$ & $\begin{array}{c}-19.98^{* * *} \\
(4.301)\end{array}$ & $\begin{array}{c}-20.30^{* * *} \\
(4.323)\end{array}$ & $\begin{array}{c}-20.01^{* * *} \\
(4.323)\end{array}$ & $\begin{array}{l}-7.156 \\
(6.839)\end{array}$ & $\begin{array}{l}-6.728 \\
(6.836)\end{array}$ & $\begin{array}{l}-6.974 \\
(6.846)\end{array}$ & $\begin{array}{l}-6.424 \\
(6.856)\end{array}$ & $\begin{array}{l}-6.433 \\
(6.852)\end{array}$ & $\begin{array}{l}-8.854 \\
(6.836)\end{array}$ \\
\hline Inflation $_{b f, t}$ & $\begin{array}{l}-0.0234 \\
(0.0413)\end{array}$ & $\begin{array}{l}-0.0174 \\
(0.0419)\end{array}$ & $\begin{array}{l}-0.0367 \\
(0.0419)\end{array}$ & $\begin{array}{l}-0.0302 \\
(0.0409)\end{array}$ & $\begin{array}{l}-0.0229 \\
(0.0413)\end{array}$ & $\begin{array}{l}-0.0294 \\
(0.0414)\end{array}$ & $\begin{array}{l}-0.168^{* *} \\
(0.0701)\end{array}$ & $\begin{array}{l}-0.118^{*} \\
(0.0700)\end{array}$ & $\begin{array}{l}-0.128^{*} \\
(0.0713)\end{array}$ & $\begin{array}{l}-0.167^{* *} \\
(0.0705)\end{array}$ & $\begin{array}{c}-0.166^{* *} \\
(0.0703)\end{array}$ & $\begin{array}{l}-0.122^{*} \\
(0.0707)\end{array}$ \\
\hline Observations & 8,747 & 8,747 & 8,747 & 8,747 & 8,747 & 8,747 & 7,150 & 7,150 & 7,150 & 7,150 & 7,150 & 7,150 \\
\hline R-squared & 0.640 & 0.637 & 0.638 & 0.638 & 0.637 & 0.638 & 0.503 & 0.503 & 0.502 & 0.501 & 0.501 & 0.508 \\
\hline Industry ${ }^{*}$ Year FE & Yes & Yes & Yes & Yes & Yes & Yes & Yes & Yes & Yes & Yes & Yes & Yes \\
\hline
\end{tabular}


Overall, these findings seem to indicate that higher quality firms that are least exposed to information asymmetries suffer a less negative effect of bank market power on their access to credit.

Third, under the information hypothesis opaque firms should benefit of higher credit availability when serviced by banks with higher market power. Findings presented in columns 6 and 12 strongly reject this hypothesis. Not only the adverse impact of market power on both bank and trade credit borrowed abates with firm's transparency, but the effect is reversed for highly transparent firms, especially for bank credit. Specifically, a one standard deviation increase in banks' Lerner is associated to a $51 \%$ decrease in short-term bank credit for a opaque firm $\left(10^{\text {th }}\right.$ percentile by transparency) as opposed to a $13 \%$ increase in bank credit for a highly transparent firm $\left(90^{\text {th }}\right.$ percentile by transparency).These results suggest that more opaque firms are more negatively affected by credit rationing, since information issues are more severe for borrowers that can post only limited physical collateral as guarantee for their borrowing (Freixas and Rochet, 2008; Bonaccorsi di Patti and Dell'ariccia, 2004).

\subsection{The effect of bank market power across SMEs}

Results presented so far highlight heterogeneity in the way bank market power affects credit availability across firms. The findings above mostly reject the information hypothesis toward the market power hypothesis. However, the foundation of the information hypothesis is relationship lending, which typically involves small and medium enterprises (SMEs), which may otherwise be financially constrained. Accordingly, in this section we provide a more stringent test of the information hypothesis by restricting the sample to SMEs. On top of being an ideal testing ground (Petersen and Rajan, 1994, 1995; Beck et al., 2004; Ryan et al., 2014a) SMEs are a fundamental component of the EU economy. As of 2016, small and medium enterprises made up $99.8 \%$ of all business, $56.8 \%$ of all value added and employing $66.6 \%$ of the work force (European Commission, 2017).

Accordingly, we carry out a more stringent test of the second theoretical predictions discussed in section 1 by estimating model (1) for SMEs only - that is, we exclude 780 firms (i.e. 1.32\% of the sample) that are outside the EU's official definition of SMEs. ${ }^{19}$ Results presented in table 4 are qualitatively similar to those related to the full sample(table 3). Higher bank market power is associated with more trade credit and less short-term bank credit for all SMEs. Looking at cross-sectional effects, higher bank market power has less of a negative impact on bank lending for large, high cash-flow and transparent SMEs, while this effect does not appear to vary by profitability and default risk. Similarly, highly transparent SMEs react to higher bank market power by drawing up less trade credit than more transparent SMEs. There is, however, no evidence of differential effect on trade credit by firm size, cash flows, profitability and default risk.

To sum up, we find no evidence supporting the information hypothesis. Lower inter-bank competition is associated to lower, not higher, credit availability for customer firms. Moreover, we find the effect of bank market power to be especially detrimental for credit availability precisely where the information hypothesis predicts it should be most beneficial - that is, for smaller, lower quality and opaque firms. We consider these results to be consistent with the market power hypothesis instead, whereby lower inter-bank competition exacerbates the financial constraint of borrowers more exposed to information asymmetries.

${ }^{19}$ Refer to footnote 18 . 
Figure 1: The heterogeneous effect of bank market power across firms

Estimated marginal effect of bank's Lerner index on credit availability as a function of firm size, cash flow and transparency, based on estimates reported in table 3.

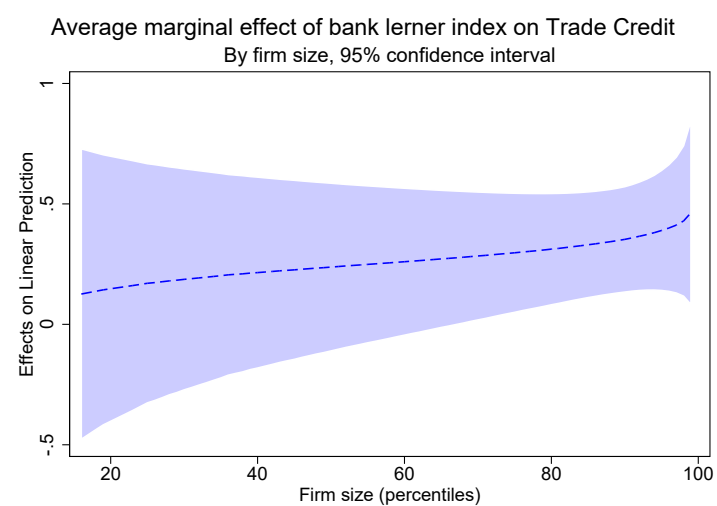

Average marginal effect of Bank lerner index on short-term Bank Credit

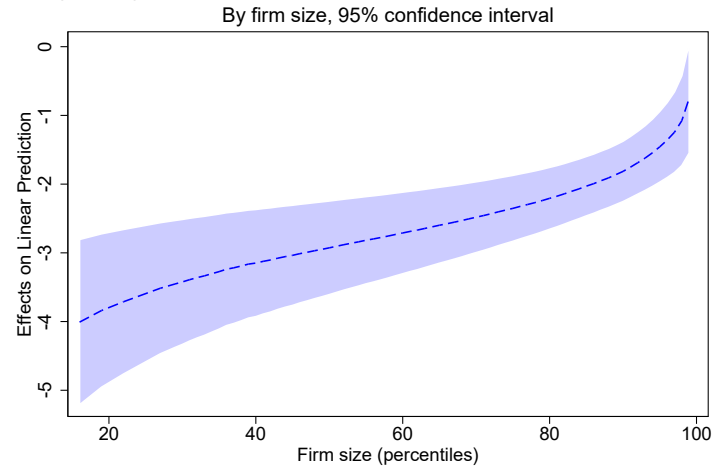

Average marginal effect of Bank lerner index on Trade Credit By firm cash flow, $95 \%$ confidence interval

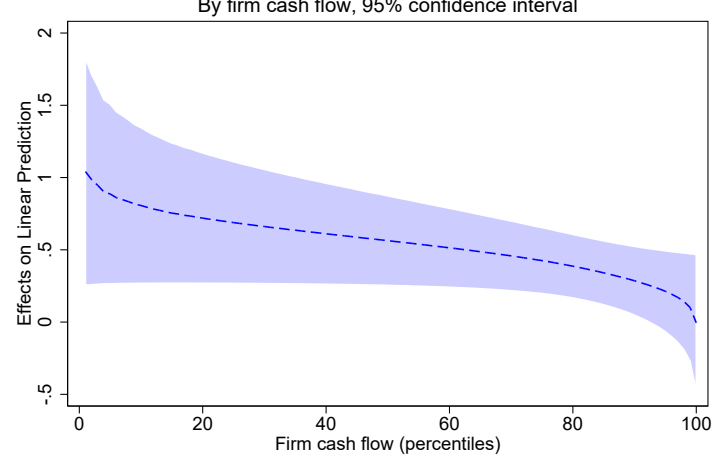

Average marginal effect of Bank lerner index on short-term Bank Credit effect of Bank lerner index on short-term

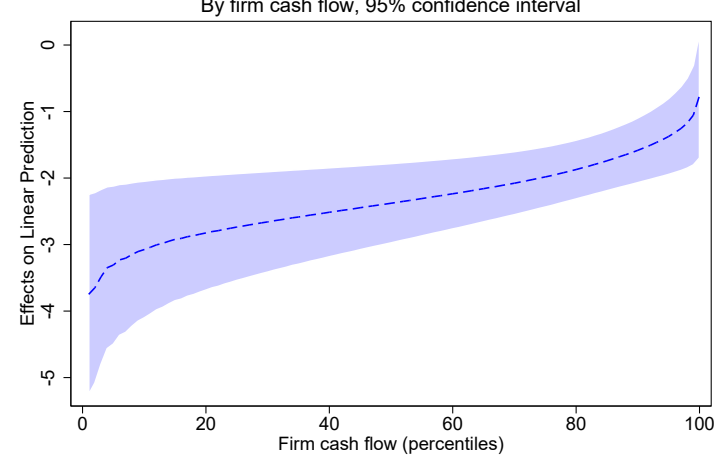

Average marginal effect of Bank lerner index on Trade Credit By firm transparency, $95 \%$ confidence interval

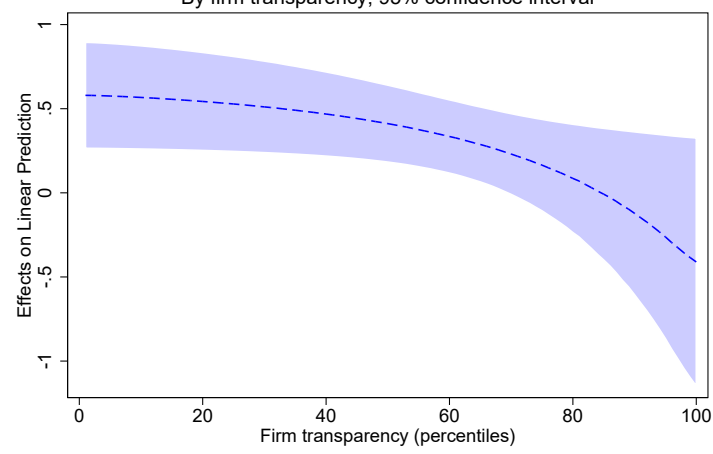

Average marginal effect of Bank lerner index on short-term Bank Credit

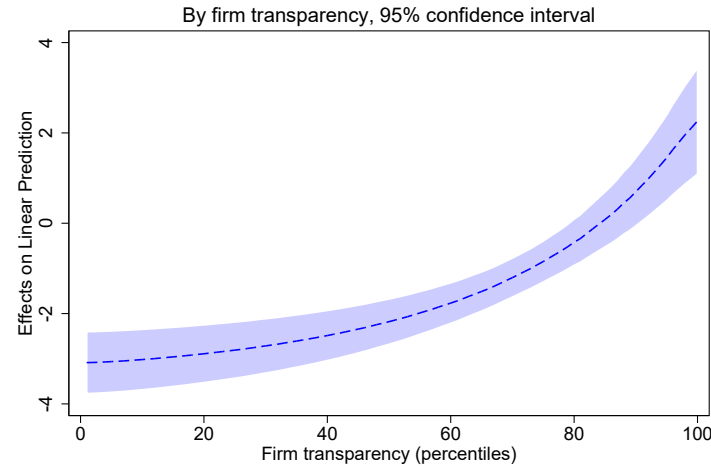




\subsection{The effect of bank market power across banks}

Finally, we test for heterogeneity in the impact of bank market power on firms' financial constraint across banks. While we found no evidence supporting the information hypothesis either directly nor across firms, we can use variation across banks to uncover evidence on the way inter-bank competition affects credit availability. In particular, in this section we test the third theoretical predictions outlined in section 1: For the information hypothesis, among banks with high market power we would expect small, local cooperatives and those with exclusive lending relationships to grant better access to credit owing to their greater interest in sustaining long term credit relationships. As before, we restrict the sample to SMEs and re-estimate model (1) focusing on the $\beta_{3}$ coefficients.

First, SMEs borrowing from small banks with high market power may obtain better credit conditions. According to Berger and Udell (2002)and Stein (2002), small banks may have a comparative advantage vis-à-vis large banks in relationship lending due to their simple organisational structure that is more congenial to the gathering of soft information.+ Therefore, for the information hypothesis one would expect that firms associated to smaller banks with larger market power benefit of larger credit availability given their banker's strong incentives to engage in relationship lending and exploit its comparative advantage vis-à-vis larger intermediaries. ${ }^{20}$ Columns 1 and 5 of table 5 provide some evidence supporting this hypothesis. On the one hand, the negative effect of bank market power on firm short-term bank borrowing is larger for SMEs served by larger banks. Specifically, a one standard deviation increase in banks' Lerner is associated to a $17 \%$ drop in short-term bank credit for a SME served by a small bank ( $10^{\text {th }}$ percentile by size $)$ as opposed to a $42 \%$ decrease in bank credit for a SME served by a large bank ( $90^{\text {th }}$ percentile). On the other hand, there are no significant differential effects across banks for trade credit: higher bank market power is associated with higher trade credit for all firms regardless of their being served by small or large banks.

Second, SMEs that borrow from cooperative banks may have easier access to credit. As compared with commercial banks, cooperatives tend to develop more enduring and stable credit relationships with firms. Furthermore, the local nature and/or cooperative ownership structure of cooperative banks may give them a competitive edge in screening and monitoring borrowers, and thus in managing asymmetric information problems typically associated with SMEs (Angelini et al., 1998). This may be because agents operating within the same community share various types of relationships and thus acquire soft information that would otherwise be available to outsiders only at a cost. Accordingly, a bank operating within a small community may exploit this informational advantage in its credit activity. Furthermore, local community banks may apply "social sanctions" which are typically not available to commercial banks (Banerjee et al., 1994). Therefore, one would expect that SMEs served by cooperative banks have larger credit availability, especially if both belong to the same local community.

\footnotetext{
${ }^{20}$ Relationship lending requires the gathering of soft information on the borrower as opposed to transaction lending that only requires hard information. In this activity, the size and organisational complexity of a bank is crucial. For smallest banks, the agency problem between management and loan officers - the likely depositary of the most valuable soft information on borrowers - is typically resolved with the president of the bank making or reviewing most of the business loans. In contrast, larger and more complex banks usually require more layers of management that may hinder the production of information-driven small business loans as opposed to their core business, i.e. transaction-driven loans and other capital market services for large firms. Furthermore, large, hierarchical firms may also be at a disadvantage in conveying the kind of soft information associated with relationship lending (Stein, 2002).
} 
Table 4: Effect of market power on firms' credit availability across SMEs

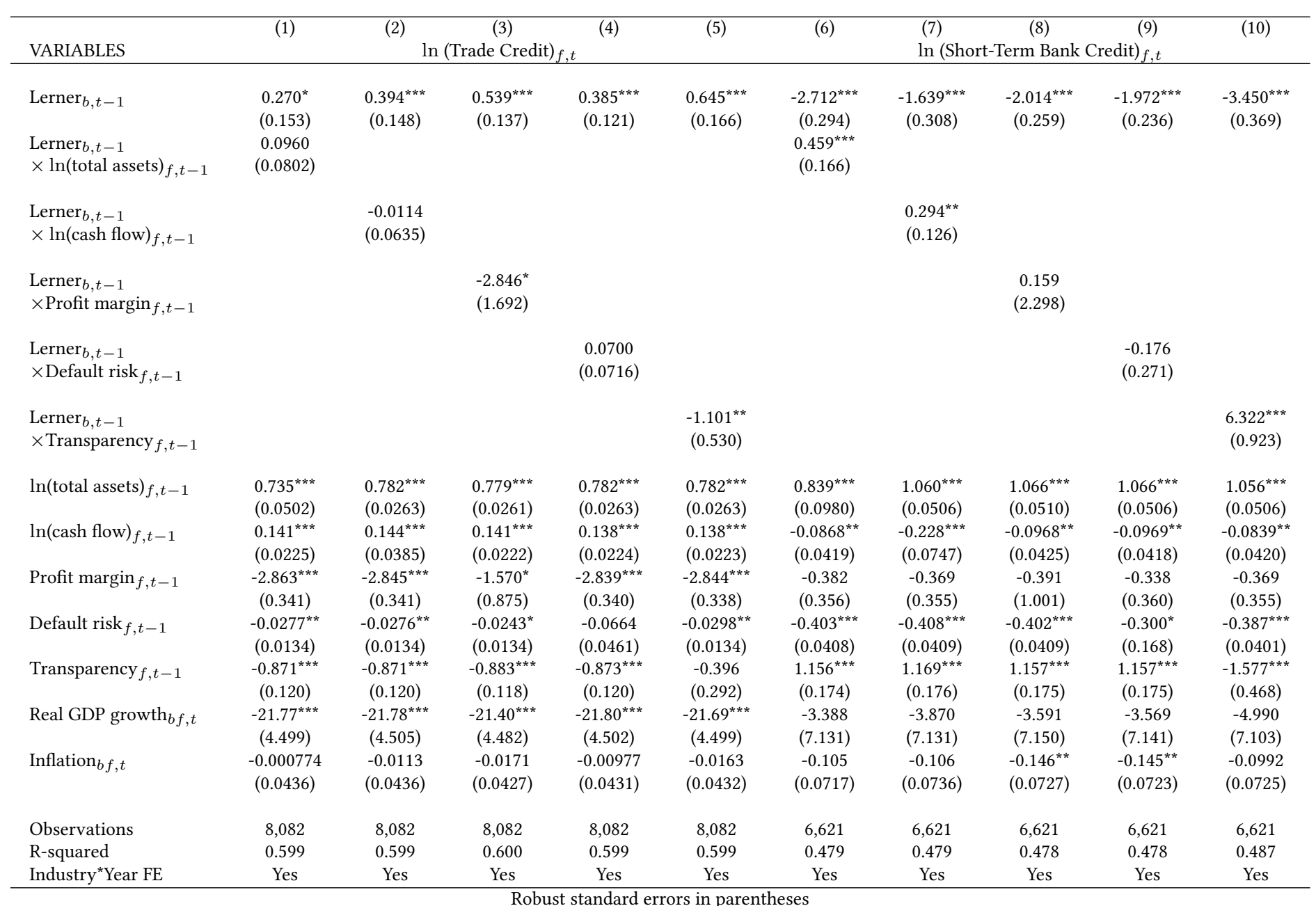

obust standard errors in parentheses 
Results reported in table 5 are consistent with this view. Columns 2 and 6 indicate that the effect of higher market power on short-term bank borrowing is less negative when the firm is linked to a cooperative than when it is linked to a commercial or a savings bank. Specifically, a one standard deviation increase in banks' Lerner is associated to a 36\% drop in short-term bank credit for SMEs linked to commercial or savings banks, while the effect is positive but not statistically different from zero for firms linked to cooperatives. Moreover, columns 3 and 7 highlight that the overall effect of bank market power on credit availability turns positive for SMEs serviced by local cooperatives, i.e. banks located in the same city as the firm. When SMEs are serviced by local cooperatives, a one standard deviation increase in banks' Lerner is associated to a $48 \%$ increase in short-term bank credit. On the other hand, SMEs served by cooperatives with high market power do not rely more on trade credit than SMEs related to other types of banks. These findings are in line with Angelini et al. (1998) and the information hypothesis, underscoring the importance of specialisation, ownership structure and local outreach in credit relationships.

Third, the information hypothesis holds that firms with relationships with a single bank should benefit from easier access to bank credit. Unique relationships typically indicate deeper and more exclusive ties between the lender and the borrower. If the information on the firm cannot be verified by other lenders, the lender may then gain an informational monopoly over the firm. Insofar this allows the lender to extract rents related to knowing that the firm is less risky than average, this should increase the availability of funds to the firm (Rajan, 1992; Sharpe, 1990). Therefore, firms uniquely related to a bank with great market power should benefit of larger credit availability vis-à-vis firms borrowing from multiple banks, ceteris paribus. This is the opposite of what we find. Estimates reported in columns 4 and 8 suggest that, for a given level of market power, single-bank firms receive less credit than firms related to multiple lenders. Specifically, a one standard deviation increase in banks' Lerner is associated to a 35\% drop in short-term bank credit for a SMEs served by a single bank, while the effect is not statistically different from zero for firms related to multiple banks. However, there is no comparable significant effect on trade credit: higher bank market power is associated with higher trade credit for all firms regardless of their being served by one or more lenders. Overall, this result may reflect the fact that, firms with multiple banking relationships can more easily switch (or credibly threaten to do so) and/or borrow from another lender (Angelini et al., 1998; Petersen and Rajan, 1994). Therefore, this effect may be explained by the lower bargaining power of single-bank firms vis-à-vis multiple-banks firms in negotiating credit terms with the bank. 
Table 5: Effect of market power on SMEs' credit availability across banks

\begin{tabular}{|c|c|c|c|c|c|c|c|c|}
\hline \multirow{3}{*}{$\begin{array}{l}\text { VARIABLES } \\
\text { Lerner }_{b, t-1}\end{array}$} & \multirow{2}{*}{\multicolumn{3}{|c|}{$\ln (\text { Trade Credit) })_{f, t}$}} & \multirow{4}{*}{$\begin{array}{c}(4) \\
\\
0.459^{*} \\
(0.272)\end{array}$} & \multirow{2}{*}{\multicolumn{4}{|c|}{$\begin{array}{cc}(6) & (7) \\
\ln (\text { Short-Term Bank } & \text { Credit) } \\
f, t\end{array}$}} \\
\hline & & & & & & & & \\
\hline & $\begin{array}{l}1.194^{* *} \\
(0.601)\end{array}$ & $\begin{array}{c}0.453^{\star * *} \\
(0.130)\end{array}$ & $\begin{array}{l}0.465^{* * *} \\
(0.132)\end{array}$ & & $\begin{array}{c}0.692 \\
(1.206)\end{array}$ & $\begin{array}{c}-2.120^{* * *} \\
(0.271)\end{array}$ & $\begin{array}{c}-2.202^{* * *} \\
(0.284)\end{array}$ & $\begin{array}{c}0.617 \\
(0.396)\end{array}$ \\
\hline $\begin{array}{l}\text { Lerner }_{b, t-1} \\
\ln (\text { total assets })_{b, t-1}\end{array}$ & $\begin{array}{l}-0.0835 \\
(0.0673)\end{array}$ & & & & $\begin{array}{c}-0.300^{* *} \\
(0.135)\end{array}$ & & & \\
\hline $\begin{array}{l}\text { Lerner }_{b, t-1} \\
\times \text { Cooperative }_{b}\end{array}$ & & $\begin{array}{c}0.124 \\
(0.554)\end{array}$ & $\begin{array}{c}0.116 \\
(0.551)\end{array}$ & & & $\begin{array}{c}2.866^{* * *} \\
(0.870)\end{array}$ & $\begin{array}{c}2.837^{* * *} \\
(0.865)\end{array}$ & \\
\hline $\begin{array}{l}\text { Lerner }_{b, t-1} \\
\times \text { Cooperative }_{b} \times \text { Same city }_{b f}\end{array}$ & & & $\begin{array}{l}-0.711 \\
(0.697)\end{array}$ & & & & $\begin{array}{l}2.180^{* *} \\
(0.927)\end{array}$ & \\
\hline $\begin{array}{l}\text { Lerner }_{b, t-1} \\
\times \text { Single bank } \\
f\end{array}$ & & & & $\begin{array}{c}0.134 \\
(0.301)\end{array}$ & & & & $\begin{array}{l}-2.725^{* * *} \\
(0.475)\end{array}$ \\
\hline $\ln (\text { total assets })_{f, t-1}$ & $\begin{array}{l}0.783^{* * *} \\
(0.0262)\end{array}$ & $\begin{array}{l}0.781^{* * *} \\
(0.0263)\end{array}$ & $\begin{array}{l}0.781^{* * *} \\
(0.0263)\end{array}$ & $\begin{array}{l}0.776^{* * *} \\
(0.0264)\end{array}$ & $\begin{array}{l}1.070^{* * *} \\
(0.0502)\end{array}$ & $\begin{array}{l}1.065^{* * *} \\
(0.0502)\end{array}$ & $\begin{array}{l}1.065^{* * *} \\
(0.0501)\end{array}$ & $\begin{array}{l}1.045^{* * *} \\
(0.0506)\end{array}$ \\
\hline $\ln ($ cash flow) $f, t-1$ & $\begin{array}{l}0.139^{* * *} \\
(0.0224)\end{array}$ & $\begin{array}{l}0.139^{* * *} \\
(0.0224)\end{array}$ & $\begin{array}{l}0.139^{* * *} \\
(0.0224)\end{array}$ & $\begin{array}{l}0.139^{\star * *} \\
(0.0227)\end{array}$ & $\begin{array}{c}-0.0982^{* *} \\
(0.0416)\end{array}$ & $\begin{array}{c}-0.0975^{* *} \\
(0.0417)\end{array}$ & $\begin{array}{c}-0.0975^{* *} \\
(0.0416)\end{array}$ & $\begin{array}{l}-0.0711^{*} \\
(0.0420)\end{array}$ \\
\hline 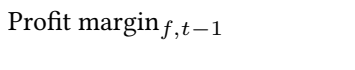 & $\begin{array}{c}-2.840^{* * *} \\
(0.340)\end{array}$ & $\begin{array}{c}-2.847^{* * *} \\
(0.340)\end{array}$ & $\begin{array}{c}-2.851^{* * *} \\
(0.340)\end{array}$ & $\begin{array}{c}-2.824^{* * *} \\
(0.342)\end{array}$ & $\begin{array}{l}-0.318 \\
(0.356)\end{array}$ & $\begin{array}{l}-0.362 \\
(0.352)\end{array}$ & $\begin{array}{l}-0.332 \\
(0.350)\end{array}$ & $\begin{array}{l}-0.428 \\
(0.354)\end{array}$ \\
\hline Default risk $_{f, t-1}$ & $\begin{array}{c}-0.0277^{* *} \\
(0.0134)\end{array}$ & $\begin{array}{c}-0.0278^{* *} \\
(0.0134)\end{array}$ & $\begin{array}{c}-0.0277^{* *} \\
(0.0134)\end{array}$ & $\begin{array}{c}-0.0278^{* *} \\
(0.0133)\end{array}$ & $\begin{array}{c}-0.401^{* * *} \\
(0.0409)\end{array}$ & $\begin{array}{l}-0.400^{* * *} \\
(0.0407)\end{array}$ & $\begin{array}{l}-0.402^{* * *} \\
(0.0401)\end{array}$ & $\begin{array}{r}-0.406^{* * *} \\
(0.0395)\end{array}$ \\
\hline $\operatorname{Transparency~}_{f, t-1}$ & $\begin{array}{c}-0.866^{* * *} \\
(0.120)\end{array}$ & $\begin{array}{c}-0.868^{* * *} \\
(0.119)\end{array}$ & $\begin{array}{c}-0.867^{* * *} \\
(0.120)\end{array}$ & $\begin{array}{c}-0.887^{* * *} \\
(0.121)\end{array}$ & $\begin{array}{c}1.168^{* * *} \\
(0.175)\end{array}$ & $\begin{array}{c}1.162^{* \star *} \\
(0.175)\end{array}$ & $\begin{array}{l}1.150^{* * *} \\
(0.176)\end{array}$ & $\begin{array}{c}1.043^{* * *} \\
(0.177)\end{array}$ \\
\hline $\ln (\text { total assets })_{b, t-1}$ & $\begin{array}{c}0.0144 \\
(0.0346)\end{array}$ & $\begin{array}{l}-0.0195 \\
(0.0154)\end{array}$ & $\begin{array}{l}-0.0209 \\
(0.0155)\end{array}$ & $\begin{array}{l}-0.0213 \\
(0.0146)\end{array}$ & $\begin{array}{l}0.0944^{*} \\
(0.0572)\end{array}$ & $\begin{array}{l}-0.0419 \\
(0.0270)\end{array}$ & $\begin{array}{l}-0.0360 \\
(0.0276)\end{array}$ & $\begin{array}{l}-0.0326 \\
(0.0257)\end{array}$ \\
\hline Real GDP growth $b f, t$ & $\begin{array}{l}-21.77^{* * *} \\
(4.495)\end{array}$ & $\begin{array}{l}-22.12^{* * *} \\
(4.814)\end{array}$ & $\begin{array}{l}-22.02^{* * *} \\
(4.821)\end{array}$ & $\begin{array}{c}-20.56^{* * *} \\
(4.499)\end{array}$ & $\begin{array}{l}-3.724 \\
(7.094)\end{array}$ & $\begin{array}{l}-7.197 \\
(7.378)\end{array}$ & $\begin{array}{l}-7.652 \\
(7.402)\end{array}$ & $\begin{array}{l}-2.645 \\
(7.125)\end{array}$ \\
\hline Inflation $_{b f, t}$ & $\begin{array}{l}-0.0146 \\
(0.0438)\end{array}$ & $\begin{array}{l}-0.0179 \\
(0.0438)\end{array}$ & $\begin{array}{l}-0.0212 \\
(0.0439)\end{array}$ & $\begin{array}{l}-0.0347 \\
(0.0436)\end{array}$ & $\begin{array}{l}-0.145^{* *} \\
(0.0730)\end{array}$ & $\begin{array}{l}-0.159^{* *} \\
(0.0735)\end{array}$ & $\begin{array}{l}-0.139^{*} \\
(0.0747)\end{array}$ & $\begin{array}{c}-0.114 \\
(0.0747)\end{array}$ \\
\hline Cooperative $_{b}$ & & $\begin{array}{l}-0.0291 \\
(0.179)\end{array}$ & $\begin{array}{c}-0.00450 \\
(0.176)\end{array}$ & & & $\begin{array}{l}-1.060^{* * *} \\
(0.280)\end{array}$ & $\begin{array}{c}-1.129^{* * *} \\
(0.283)\end{array}$ & \\
\hline Same city $b f$ & & & $\begin{array}{c}0.0312 \\
(0.0687)\end{array}$ & & & & $\begin{array}{l}-0.203 \\
(0.145)\end{array}$ & \\
\hline Single bank $_{f}$ & & & & $\begin{array}{l}-0.207 \\
(0.138)\end{array}$ & & & & $\begin{array}{c}0.713^{* * *} \\
(0.213)\end{array}$ \\
\hline Observations & 8,082 & 8,082 & 8,082 & 8,082 & 6,621 & 6,621 & 6,621 & 6,621 \\
\hline R-squared & 0.599 & 0.599 & 0.599 & 0.600 & 0.479 & 0.479 & 0.480 & 0.484 \\
\hline Industry ${ }^{*}$ Year FE & Yes & Yes & Yes & Yes & Yes & Yes & Yes & Yes \\
\hline
\end{tabular}




\section{Conclusion}

In this paper we investigated how inter-bank competition affects firms' credit availability using a firm-bank matched database to test for the information and market power hypotheses. The former holds that lower competition encourages banks to establish long-term relationships with firms, thus improving credit availability; the latter expects bank market power to worsen credit conditions for borrowers owing to misallocations and distortions generally associated to the lack of competition.

Results reject the information hypothesis in favour of the market power hypothesis. Lower inter-bank competition is associated to lower, not higher, credit availability for customer firms. Furthermore, the fact that trade and bank credit move in the opposite direction suggests that firms linked to banks with high market power are more credit constrained and more likely to turn to alternative more expensive sources of finance than firms linked to banks with low market power.

Looking at the cross-section of firms, we find the effect of bank market power on credit availability to be especially detrimental precisely where the information hypothesis predicts it should be most beneficial: For a given level of bank market power, small, low quality and opaque firms receive less short-term bank credit and more trade credit than large, high quality and transparent firms. Importantly, we find the same cross-sectional results by restricting the sample to SMEs only. Furthermore, for a given level of bank market power SMEs related to a single bank obtain less short-term bank credit than SMEs serviced by multiple banks. We find only limited evidence supporting the information hypothesis in the cross-section of banks. For a given level of bank market power SMEs related to a smaller cooperative banks obtain more short-term bank credit than SMEs serviced by larger commercial lenders, and the effect is magnified when firm and bank are located in the same city.

Overall, we consider our results to be mainly consistent with the market power hypothesis, whereby lower inter-bank competition exacerbates the financial constraint of borrowers more exposed to information problems. Our findings suggest inter-bank competition may be benefit access to credit especially by encouraging credit relationships established the local level, between small cooperative banks and small firms who have a particular interest in forming longterm ties.

These findings have direct implications for policy. The current impetus towards cross-country banking consolidation in the EU has the potential to significantly increase the market power of individual banking groups and to lower the level of competition in the banking sector. While policy makers have so far generally welcomed and encouraged these activities, our results suggests that efficiency and financial stability considerations should be weighed against the potential negative consequences for firms' access to credit, especially for small and medium enterprises.

\section{References}

Aghion, P., Bloom, N., Blundell, R., Griffith, R., Howitt, P., 2005. Competition and innovation: an inverted-u relationship. The Quarterly Journal of Economics 120 (2), 701-728.

Agostino, M., Trivieri, F., 2014. Does trade credit play a signalling role? some evidence from smes microdata. Small Business Economics 42 (1), 131-151.

Amiti, M., Weinstein, D., 2011. Exports and financial shocks. The Quarterly Journal of Economics 126 (4), 1841-1877. 
Andrieu, G., Stagliano, R., Zwan, P., June 2018. Bank debt and trade credit for SMEs in Europe: firm, industry, and country-level determinants. Small Business Economics 51 (1), 245-264.

Angelini, P., Di Salvo, R., Ferri, G., 1998. Availability and cost of credit for small businesses: Customer relationships and credit cooperatives. Journal of Banking and Finance 22 (6-8), 925954.

Anginer, D., Demirguc-Kunt, A., Zhu, M., 2014. How does competition affect bank systemic risk? Journal of Financial Intermediation 23 (1), 1-26.

Banerjee, A. V., Besley, T., Guinnane, T. W., may 1994. Thy Neighbor's Keeper: The Design of a Credit Cooperative with Theory and a Test. The Quarterly Journal of Economics 109 (2), 491515.

Beck, T., Demirguc Kunt, A., Maksimovic, V., 2004. Bank competition and access to finance: international evidence. Proceedings, 627-654.

Beck, T., Demirgüç-Kunt, A., Maksimovic, V., sep 2008. Financing patterns around the world: Are small firms different? Journal of Financial Economics 89 (3), 467-487.

Beck, T., Jonghe, O. D., Schepens, G., 2013. Bank competition and stability: Cross-country heterogeneity. Journal of Financial Intermediation 22 (2), $218-244$.

Berger, A., Klapper, L., Turk-Ariss, R., 2009. Bank competition and financial stability. Journal of Financial Services Research 35 (2), 99-118.

Berger, A., Udell, G., 1995. Relationship lending and lines of credit in small firm finance. The Journal of Business 68 (3), 351-81.

Berger, A. N., et al, 2004. Bank concentration and competition: An evolution in the making. Journal of Money, Credit and Banking 36 (3), 433-51.

Berger, A. N., Hannan, T. H., 1989. The price concentration relationship in banking. Review of Economics and Statistics 71, 291fi??99.

Berger, A. N., Udell, G. F., February 2002. Small Business Credit Availability and Relationship Lending: The Importance of Bank Organisational Structure. Economic Journal 112 (477), 3253.

Bikker, J., Shaffer, S., Spierdijk, L., 01 2009. Assessing competition with the panzar-rosse model: The role of scale, costs, and equilibrium 94.

Bonaccorsi di Patti, E., Dell'ariccia, G., 2004. Bank competition and firm creation. Journal of Money, Credit and Banking 36 (2), 225-51.

Carbo Valverde, S., Francisco, R.-F., Gregory F, U., 2009. Bank market power and sme financing constraints. Review of Finance 13, 309-340.

Cetorelli, N., 2001a. Banking market structure, financial dependence and growth: International evidence from industry data. Journal of Finance 56 (2), 617-648.

Cetorelli, N., 2001b. Competition among banks: good or bad? Economic Perspectives (Q II), 38-48. 
Chodorow-Reich, G., 2014. The employment effects of credit market disruptions: Firm-level evidence from the 2008-9 financial crisis. The Quarterly Journal of Economics 129 (1), 1-59.

Claessens, S., Laeven, L., 2004. Competition in the Financial Sector and Growth: A Cross-Country Perspective. In: Financial Development and Economic Growth. Palgrave Macmillan UK, London, pp. 66-105.

Cressy, R., Olofsson, C., 1997. European sme financing: An overview. Small Business Economics $9(2), 87-96$.

Degryse, H., Cerqueiro, G., Ongena, S., 2007. Distance, Bank Organizational Structure and Credit. Tech. rep.

Dell Ariccia, G., Marquez, R., 2006. Lending booms and lending standards. Journal of Finance 61 (5), 2511-2546.

Demirguc-Kunt, A., Peria, M. S. M., 2010. A Framework for Analyzing Competition in the Banking Sector. World Bank Policy Research (Working Paper No. 5499).

Drechsler, I., Savov, A., Schnabl, P., 2017. The Deposits Channel of Monetary Policy. The Quarterly Journal of Economics 132 (4), 1819-1876.

Dun, Breadstreet, 1970. Handbook of Credit Terms. (Dun and Breadstreet, New York).

Ellienhausen, G., Wolken, J., 1993. The use of trade credit by small businesses. Board of Governors of the Federal Reserve System.

European Commission, 2017. Annual Report on European SMEs. European Commission Report.

Freixas, X., Rochet, J.-C., 2008. Microeconomics of banking. MIT Press.

Fungacova, Z., Solanko, L., Weill, L., 2014. Does competition influence the bank lending channel in the euro area? Journal of Banking and Finance 49 (C), 356-366.

Fungáčová, Z., Solanko, L., Weillb, L., 2014. Does competition influence the bank lending channel in the euro area? Journal of Banking \& Finance 49, 356-366.

Giannetti, M., Burkart, M., Ellingsen, T., 2011. What you sell is what you lend? explaining trade credit contracts. Review of Financial Studies 24 (4), 1261-1298.

Guzman, M. G., Sep 2000. Bank structure, capital accumulation and growth: a simple macroeconomic model. Economic Theory 16 (2), 421-455.

Hannan, T. H., 1997. Market share inequality, the number of competitors, and the hhi: An examination of bank pricing. Review of Industrial Organization 12 (1), 23-35.

Hannan, T. H., Berger, A. N., September 1991. The rigidity of prices: Evidence from the banking industry. American Economic Review 81 (4), 938-945.

Jackson, W. E., 1997. Market structure and the speed of price adjustments: Evidence of nonmonotonicity. Review of Industrial Organization 12 (1), 37-57.

Jayaratne, J., Wolken, J., 1999. How important are small banks to small business lending?: New evidence from a survey of small firms. Journal of Banking and Finance 23 (2-4), 427-458. 
Langfield, S., Pagano, M., 2016. Bank bias in europe: effects on systemic risk and growth. Economic Policy 31 (85), 51-106.

Leon, F., 2015. Does bank competition alleviate credit constraints in developing countries? Journal of Banking and Finance 57, 130 - 142.

Love, I., Martínez Pería, M. S., jan 2015. How Bank Competition Affects Firms' Access to Finance. The World Bank Economic Review 29 (3), 413-448.

Marquez, R., 2002. Competition, adverse selection, and information dispersion in the banking industry. Review of Financial Studies 15 (3), 901-926.

Maudos, J., Fernndez de Guevara, J., 2007. The cost of market power in banking: Social welfare loss vs. cost inefficiency. Journal of Banking and Finance 31 (7), 2103-2125.

Mayer, C., 1988. New Issues in Corporate Finance. European Economic Review 32, 1167-1189.

Nilsen, J., 2002. Trade credit and the bank lending channel. Journal of Money, Credit and Banking 34 (1), 226-53.

Nuoy, D., 2017. Too much of a good thing? The need for consolidation in the European banking sector. Speech at the VIII Financial Forum, Madrid, 27 September.

Pagano, M., 1993. Financial markets and growth: An overview. European Economic Review 37 (23), 613-622.

Panzar, J. C., Rosse, J. N., 1987. Testing for monopoly equilibrium. Journal of Industrial Economics 35 (4), 443-56.

Petersen, M., Rajan, R., 1994. The benefits of lending relationships: Evidence from small business data. Journal of Finance 49 (1), 3-37.

Petersen, M. A., Rajan, R., 1995. The effect of credit market competition on lending relationships. The Quarterly Journal of Economics 110 (2), 407-443.

Rajan, R., 1992. Insiders and outsiders: The choice between informed and arm's-length debt. Journal of Finance 47 (4), 1367-400.

Rhoades, S. A., 1995. Market share inequality, the hhi, and other measures of the firm-composition of a market. Review of Industrial Organization 10 (6), 657-674.

Roy, A. D., 1952. Safety first and the holding of assets. Econometrica 20 (3), 431-449.

Ryan, R., Conor, O. T., McCann, F., 2014a. Does bank market power affect sme financing constraints. Journal of Banking and Finance 49, 495 - 505.

Ryan, R. M., O’Toole, C. M., McCann, F., dec 2014b. Does bank market power affect SME financing constraints? Journal of Banking \& Finance 49, 495-505.

Schaeck, K., Cihák, M., 2012. Banking Competition and Capital Ratios. European Financial Management.

Schoenmaker, D., Wierts, P., 2015. Regulating the financial cycle: An integrated approach with a leverage ratio. Economics Letters 136 (C), 70-72. 
Sharpe, S., 1990. Asymmetric information, bank lending, and implicit contracts: A stylized model of customer relationships. Journal of Finance 45 (4), 1069-87.

Stein, J. C., oct 2002. Information Production and Capital Allocation: Decentralized versus Hierarchical Firms. The Journal of Finance 57 (5), 1891-1921.

Vives, X., 2001. Competition in the changing world of banking. Oxford Review of Economic Policy 17 (4), 535-547.

Zarutskie, R., 2006. Evidence on the effects of bank competition on firm borrowing and investment. Journal of Financial Economics 81 (3), 503-537. 


\section{Appendix A Estimating the Lerner index}

The Lerner index is defined as the ratio of the difference between price of output and marginal cost to the price. The price of output is the average price of bank output computed as the ratio of total income to total assets. The marginal cost is obtained by estimating a translogarithmic cost function with one output (total asset), and three proxies for input prices (labour, borrowing and capital). As in Demirguc-Kunt and Peria (2010) we estimate the following model:

$$
\begin{aligned}
& \ln (T C)_{b t}=\alpha_{0}+\alpha_{1} y_{b t}+\frac{1}{2} \alpha_{2}\left(\ln y_{b t}\right)^{2}+\sum_{j=1}^{3} \beta_{j} \ln w_{b t, j}+\sum_{j=1}^{3} \sum_{k=1}^{3} \beta_{j k} \ln w_{b t, j} \times \ln w_{b t, k} \\
& \quad+\frac{1}{2} \sum_{j=1}^{3} \gamma_{j} \ln w_{b t, j} \times \ln y_{b t}+\operatorname{Trend}_{t}\left(\delta_{1}+\delta_{2} \operatorname{Trend}_{t}+\delta_{3} \ln y_{b t}+\sum_{j=1}^{3} \delta_{4} \ln w_{b t, j}\right)+\epsilon_{b, t}
\end{aligned}
$$

where $b$ stands for banks and $t$ for years. In model (1), $T C$ denotes total costs (sum of total interest paid and operating costs), $y$ total banking assets, $w_{1}$ labour price (staff expenses divided by total assets), $w_{2}$ the price of physical capital (non-interest expenses divided by total assets) and $w_{3}$ the price of borrowed funds (total interest paid divided by customer and short term funding). ${ }^{21}$ Model (2) is estimated on a sample of 3650 euro area banks extracted from Orbis Bank Focus covering the period 2010-2016. The estimation is carried out country by country with bank-fixed effects. The estimated coefficients are employed to derive the marginal cost (MC):

$$
\widehat{M C_{b, t}}=\frac{T C_{b, t}}{y_{b, t}}\left(\hat{\alpha_{1}}+\hat{\alpha_{2}} \ln y_{b, t}+\frac{1}{2} \sum_{j=1}^{3} \hat{\gamma}_{j} \ln w_{b, t, j}+\hat{\delta_{3}} \text { Trend }_{t}\right)
$$

Finally, the bank-specific Lerner index is obtained as:

$$
\text { Lerner }_{b, t}=\frac{P_{b, t}-\widehat{M C_{b, t}}}{P_{b, t}}
$$

\footnotetext{
${ }^{21}$ To minimise the incidence of outliers, all variables are winsorised at the 1 st and 99th percentiles.
} 


\section{Appendix B On the relation between firms and main banks}

Bank credit obtained by firms may be an invalid proxy for the unobserved share of borrowing from the main banks. To test for its validity we first aggregate firm bank credit across firms for each bank, so to create a bank level variable that collects all bank borrowing by firms connected to that bank. While this is measure is spurious as banks (firms) likely lend (borrow) to other firms (from other banks) unreported in our database, unconditional correlations between bank and firm variables are high: the aggregate borrowing of firms moves closely to the total lending, total assets, leverage and non-performing loans (NPL) of the bank reported as their main lender (first column of table 6. This suggests there are indeed interdependencies between borrowers and lenders that may reflect credit relations.

Table 6: Pair-wise correlations between aggregate firm bank borrowing and banks' balance sheet variables, $\mathrm{p}$-values in parentheses.

\begin{tabular}{l|cccc}
\hline \multirow{2}{*}{ ln bank loans } & $\begin{array}{c}\text { ln sum of firm } \\
\text { borrowing by bank }\end{array}$ & $\begin{array}{c}\text { ln bank } \\
\text { loans }\end{array}$ & $\begin{array}{c}\text { ln bank } \\
\text { total assets }\end{array}$ & $\begin{array}{c}\text { bank equity } \\
\text { /total assets }\end{array}$ \\
\hline \hline \multirow{4}{*}{ ln bank total assets } & 0.3887 & & & \\
& $(0.0000)$ & & & \\
& 0.3543 & 0.9877 & & \\
Equity/total assets & $(0.0000)$ & $(0.0000)$ & & \\
& & & & \\
& 0.314 & -0.3083 & -0.3252 & \\
ln bank & $(0.0000)$ & $(0.0000)$ & $(0.0000)$ & \\
NPL & & & & \\
\hline \hline
\end{tabular}

Still, it may be that firm aggregate borrowing and bank total lending co-move due to common cyclical trends. To check for that, we regress firm total borrowing on bank total lending conditional on several macroeconomic indicators. Estimates are reported in table 7. Conditional analysis confirms that firm aggregate borrowing by bank is correlated with bank total loans even when controlling for cyclical factors. Elasticities coefficients are positive and significant. For instance, $1 \%$ increase in bank loans is associated to a $77.5 \%$ increase in aggregate firm borrowing. 
Table 7: Relation between aggregate firm borrowing and banks' balance sheets

\begin{tabular}{|c|c|c|c|c|}
\hline \multirow[b]{2}{*}{ Variables } & (1) & (2) & (3) & $(4)$ \\
\hline & \multicolumn{4}{|c|}{$\ln (\text { sum of firm borrowing by bank })_{b, t}$} \\
\hline $\ln (\text { Loans })_{b, t}$ & $\begin{array}{c}77.53^{* * *} \\
(0.711)\end{array}$ & & & \\
\hline $\ln (\text { Total assets })_{b, t}$ & & $\begin{array}{c}59.65^{* * *} \\
(0.778)\end{array}$ & & \\
\hline Equity/assets $_{b, t}$ & & & $\begin{array}{c}1,530^{* * *} \\
(12.98)\end{array}$ & \\
\hline $\ln \left(\mathrm{NPL}_{b, t}\right.$ & & & & $\begin{array}{l}69.90^{* * *} \\
(-1.013)\end{array}$ \\
\hline Real GDP growth grtt $_{b}$ & $\begin{array}{c}-13,307^{* * *} \\
(180.3)\end{array}$ & $\begin{array}{c}-55,917^{* * *} \\
(196.7)\end{array}$ & $\begin{array}{c}-55,527^{* * *} \\
(191.6)\end{array}$ & $\begin{array}{c}-59,691^{* * *} \\
(213.3)\end{array}$ \\
\hline Inflation $_{b, t}$ & $\begin{array}{c}163.4^{* * *} \\
-3.195\end{array}$ & $\begin{array}{l}56.44^{* * *} \\
(-3.130)\end{array}$ & $\begin{array}{l}8.177^{* * *} \\
(-2.960)\end{array}$ & $\begin{array}{l}47.52^{* * *} \\
(-3.430)\end{array}$ \\
\hline Spread $_{b, t}$ & $\begin{array}{c}-15,372^{* * *} \\
(106.4)\end{array}$ & $\begin{array}{c}-39,649^{* * *} \\
(116.0)\end{array}$ & $\begin{array}{c}-44,189^{* * *} \\
(108.5)\end{array}$ & $\begin{array}{c}-42,698^{* * *} \\
(125.1)\end{array}$ \\
\hline Observations & 278,439 & 171,53 & 171,516 & 145,507 \\
\hline R-squared & 0.182 & 0.568 & 0.587 & 0.523 \\
\hline Year FE & Yes & Yes & Yes & Yes \\
\hline
\end{tabular}

\section{Appendix C Estimating the H-statistic}

A large number of studies measured bank competition with the Panzar-Ross H-statistic (Panzar and Rosse, 1987), which captures the elasticity of banks revenues relative to input prices. The $\mathrm{H}$-statistic takes values between 0 and 1 . By way of interpretation, when the H-statistic takes the value of 1 , the market is under perfect competition, when it takes the value of 0 the market is under a monopoly and between 0 and 1 the system operates under monopolistic competition. Indeed, under perfect competition, an increase in input prices raises both marginal costs and total revenues by the same amount, and hence the $\mathrm{H}$-statistic equals 1 . Under a monopoly, an increase in input prices results in a rise in marginal costs, a fall in output, and a decline in revenues, leading to a H-statistic less than or equal to 0. Following Demirguc-Kunt and Peria (2010) we estimate the following model:

$$
\ln P_{b, t}=\alpha_{i}+\beta_{1} \ln w_{1, b, t}+\beta_{2} \ln w_{2, b, t}+\beta_{3} \ln w_{3, b, t}+\ln w_{i, b, k}+y \ln Z_{b, t}+\delta D_{t}+\varepsilon_{b, t}
$$

where $\mathbf{b}$ denote banks and $\mathrm{t}$ denotes years. As for the Lerner index, $w_{1} w_{2}$ and $w_{3}$ denote the input prices of deposits, labour and capital, respectively. $\mathrm{Z}$ is a matrix of controls that includes the ratio of equity over total assets, net loans over total assets and the natural logarithm of total assets. $\mathrm{D}$ is a vector of year dummies and $\alpha_{1}$ denotes bank fixed effects.

The H-statistic is then calculated as $H=\hat{\beta}_{1}+\hat{\beta}_{2}+\hat{\beta}_{3}$. 